\title{
Nondestructive Evaluation of the VSC-17 Cask
}

Al Carlson

Cecilia Hoffman

Sheryl Morton

James Rivera

Phil Winston

Koji Shirai

Shin Takahashi

Masahiro Tanaka

January 2006

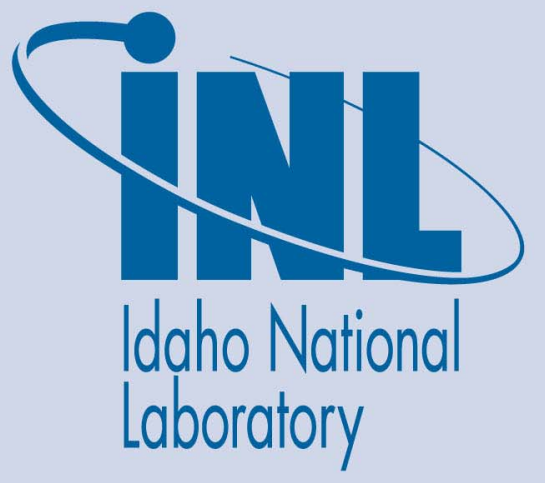

The INL is a U.S. Department of Energy National Laboratory operated by Battelle Energy Alliance 
INL/EXT-05-00968

\title{
Nondestructive Evaluation of the VSC-17 Cask
}

\author{
Al Carlson \\ Cecilia Hoffman \\ Sheryl Morton \\ James Rivera \\ Phil Winston \\ Koji Shirai \\ Shin Takahashi \\ Masahiro Tanaka
}

January 2006

Idaho National Laboratory
Idaho Falls, Idaho 83415

Prepared for the

Central Research Institute of Electric Power Industry and the U.S. Department of Energy

Under DOE Idaho Operations Office

Contract DE-AC07-05ID14517 


\begin{abstract}
In 2003, representatives from the Central Research Institute of Electric Power Industry (CRIEPI) requested development of a project with the objective of determining the performance of a concrete spent nuclear fuel storage cask. Radiation and environmental effects may cause chemical alteration of the concrete that could result in excessive cracking, spalling, and loss of compressive strength. The Idaho National Laboratory (INL) project team and CRIEPI representatives identified the Ventilated Storage Cask (VSC-17) spent nuclear fuel storage cask, originally located at the INL Test Area North, as a candidate to study cask performance because it had been used to store fuel as part of a dry cask storage demonstration project for over 15 years.
\end{abstract}

The project involved investigating the properties of the concrete shield. INL performed a survey of the cask in the summers of 2003 and 2004. The INL team met with the CRIEPI representatives in December of 2004 to discuss the next steps. As a result of that meeting, CRIEPI requested that in the summer 2005 INL perform additional surveys on the VSC-17 cask with participation of CRIEPI scientists.

This document summarizes the evaluation methods used on the VSC-17 to evaluate the cask for compressive strength, concrete cracking, concrete thickness, and temperature distribution. 


\section{ACKNOWLEDGMENTS}

Assistance in performing testing was provided by Lisa Jorgensen and C. J. Justice of Idaho Nuclear Technology and Engineering Center Quality Assurance, and H. Craig Bean and Russell Jones of the Materials Testing Laboratory. Thermal imaging was performed by Jerry Bingham and Darrel Johnson. Additional assistance was provided by Marc Dela George and Damson Ortega in performing supplemental radiation measurements. Operations support was provided by Leo Montie and Richard Jones. Management coordination and support was provided by Wyn Schwendiman and Mary Anne Willmore. 


\section{CONTENTS}

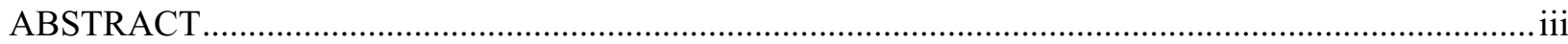

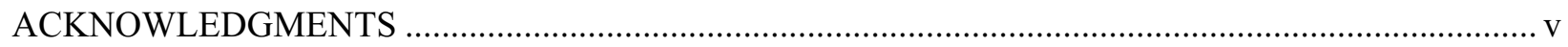

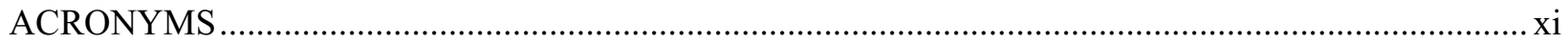

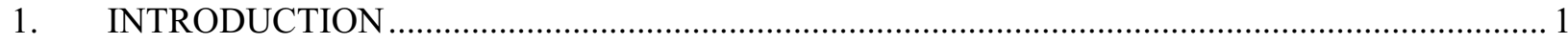

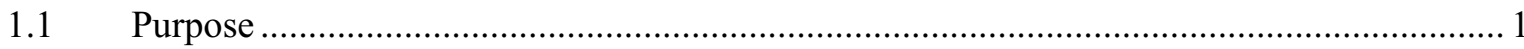

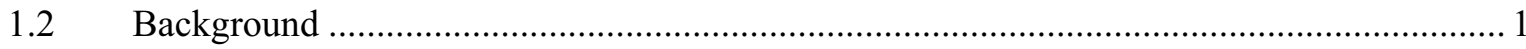

$1.3 \quad$ Description of Cask and Cask Move ........................................................................ 1

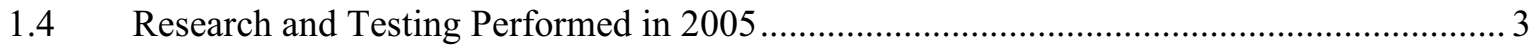

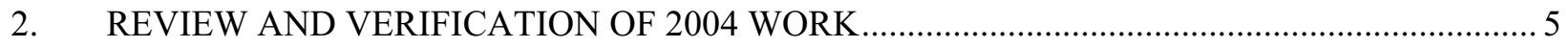

2.1 Expected Radiation Profile for the Fuel Stored in the VSC-17 Cask ................................5

2.2 Weather Data for 2004 Temperature Test ............................................................... 6

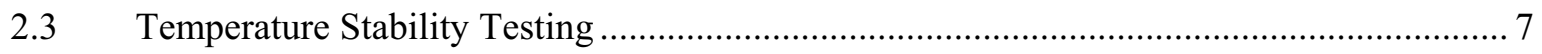

2.4 Measurement Using Bare Thermocouple to Measure Annulus Temperature ..................... 8

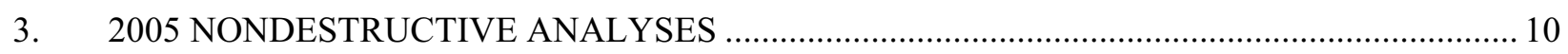

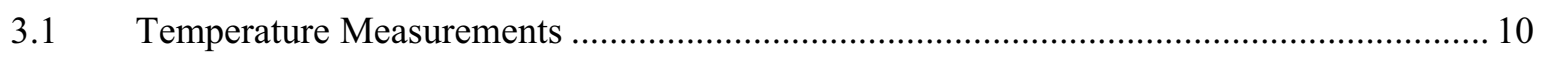

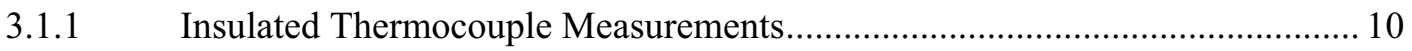

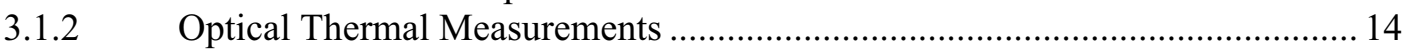

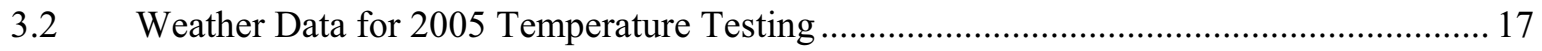

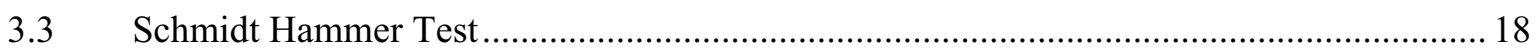

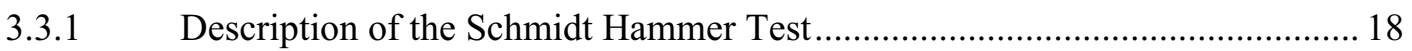

3.3.2 VSC-17 Hammer Test ........................................................................................ 19

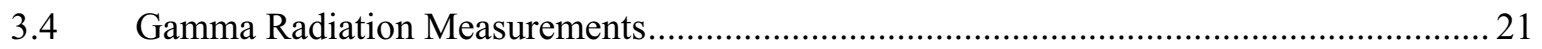

3.4.1 2005 Measurements (with Clarifications for 2004 Report)............................ 22

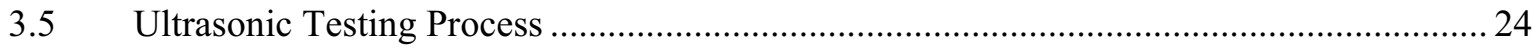

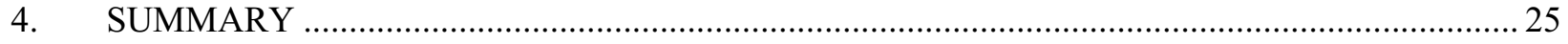

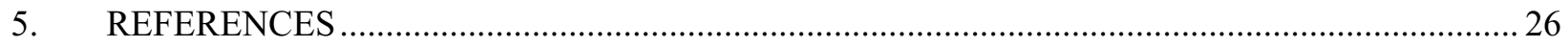




\section{FIGURES}

1. Former and current locations of the VSC-17 cask at the Idaho National Laboratory ...................... 2

2. The VSC-17 is the third cask from the right as it is currently stored on the CPP-2707 pad at INTEC

3. VSC-17 cask transported to INTEC in October 2004 (additional pictures on enclosed CD)............ 4

4. Gross gamma scan of fuel assembly D01 (Reference 1) …...................................................... 5

5. Gross gamma scan or the fuel assembly skeleton D01 (Reference 1) ........................................... 6

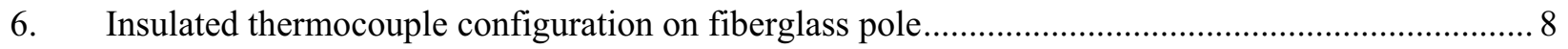

7. Laboratory building wall test of insulated thermocouple rake .................................................. 9

8. Surface temperature measurements were obtained using a thermocouple rake ............................. 11

9. Electrical conduit is visible from behind the VSC-17 cask, which prevented obtaining surface temperature measurements on the west side of the cask ....................................................... 11

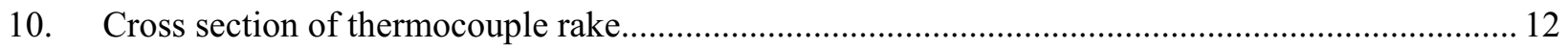

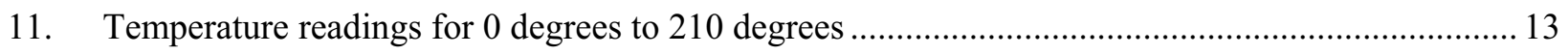

12. Surface temperature data from the radial 340 degrees through 210 degrees locations ................... 14

13. Thermocouple rake measurements and corresponding adjusted emissivity (image by Jerry Bingham).

14. Infrared image of casks taken at INTEC (photo by Darrell Johnson) …....................................... 16

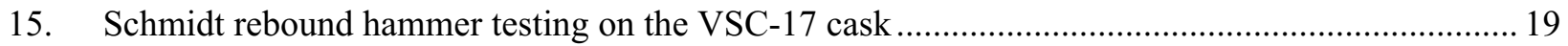

16. Layout of Schmidt rebound hammer test locations and gross gamma radiation

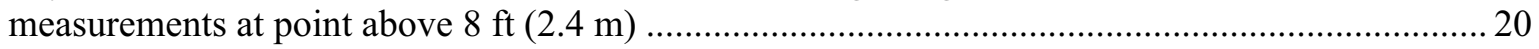

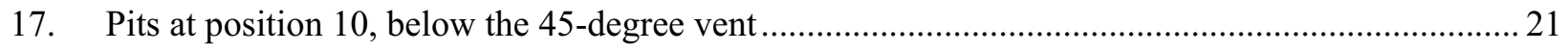

18. Age-strength relationships for moist-cured concrete ............................................................. 22

19. Comparison of 2003 and 2005 collimated measurements ..................................................... 22

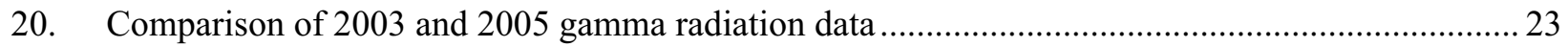

21. CRIEPI and LAZOC Inc. representatives performed ultrasonic testing in August 2005 ................24 


\section{TABLES}

1. Tabular listing of weather conditions for July 12, 2004, from 11:00 a.m. to 12:00 p.m ................. 7

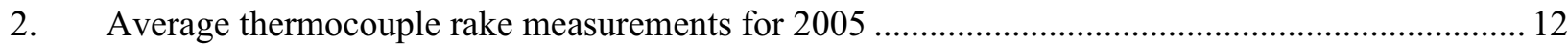

3. Weather conditions during the July 27, 2005, period in which temperature data were gathered on the surface of the VSC-17 cask.

4. Tabular listing: July 27, 2005-11:00 through July 27, 2005, 14:00 MDT …............................ 17

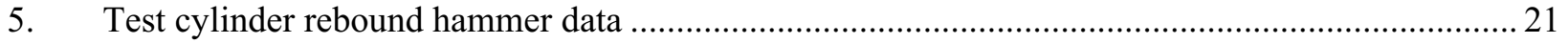

6. Comparison of gamma radiation readings for the 52-degree radial position. Data for comparison are visually shown in Figures 19 and 20 


\section{ACRONYMS}

ASTM American Society of Testing and Materials

CRIEPI Central Research Institute of Electric Power Industry

DRCT Dry Rod Consolidation Technology (project)

INL Idaho National Laboratory

INTEC Idaho Nuclear Technology and Engineering Center

MSB multi-element sealed basket

PWR pressurized water reactor

SNF spent nuclear fuel

TAN Test Area North

VCC Ventilated Concrete Cask

VSC Ventilated Storage Cask 


\section{Nondestructive Evaluation of VSC-17 Cask \\ 1. INTRODUCTION}

\subsection{Purpose}

This report provides a discussion of the nondestructive examination methods used in the summer 2005 on the Pacific Sierra Nuclear VSC-17 ventilated storage cask (VSC) for spent nuclear fuel (SNF). The VSC-17 is located at the Idaho National Laboratory (INL) Idaho Nuclear Technology and Engineering Center (INTEC). INL and the Central Research Institute of Electric Power Industry (CRIEPI) jointly evaluated the VSC-17 concrete shield for compressive strength, cracking, thickness, and temperature distribution to study the aging effect of radiation and the environment on the storage cask. The team used a concrete hammer test, ultrasonic testing, thermocouples, and thermal imaging to perform the 2005 testing activities.

\subsection{Background}

Durability of the concrete shielding on a concrete SNF storage cask is a key design attribute that dictates the usability of these casks for long-term storage. Radiation and environmental effects may cause chemical alteration of the concrete and could result in excessive cracking, spalling, and loss of compressive strength. In 2003, representatives from CRIEPI requested development of a project with the objective of determining the performance of a concrete SNF storage cask. The INL project team and CRIEPI representatives identified the VSC-17 SNF storage cask located at INTEC (originally located at the INL Test Area North [TAN] facility) as a candidate to study cask performance because it had been used to store fuel as part of a dry cask storage demonstration project for over 15 years.

The project team focused on investigating the properties of the concrete shield. INL performed a survey of the cask in the summers of 2003 and 2004. During that period, INL obtained data on radiation and temperature. Preliminary evaluations indicated that the cask has no visual degradation. However, a 4 to $5-\mathrm{mrem} / \mathrm{hr}$ step change in the radiation levels about halfway up the cask and a localized hot spot beneath an upper air vent indicate that there may be variability in the density of the concrete or localized cracking. CRIEPI performed ultrasonic testing on a one-eighth scale model of the cask, which suggested that achieving uniform concrete placement underneath the metal vent structure was difficult and that variations in radiological shielding may be more a function of manufacturing quality than aging degradation. To determine the reason for these variable radiation readings, the INL and CRIEPI project team performed follow-on nondestructive examination measurements on the VSC-17 in 2005.

\subsection{Description of Cask and Cask Move}

INL (Figure 1), located on the Snake River Plain in southeast Idaho, maintained the VSC-17 cask on the TAN storage pad, TAN-791, from 1989 to 2004. The concrete shielding component of the cask was fabricated on site in 1989. The cask was moved to the INTEC CPP-2707 pad in October 2004 where it continues to be stored (Figure 2). 


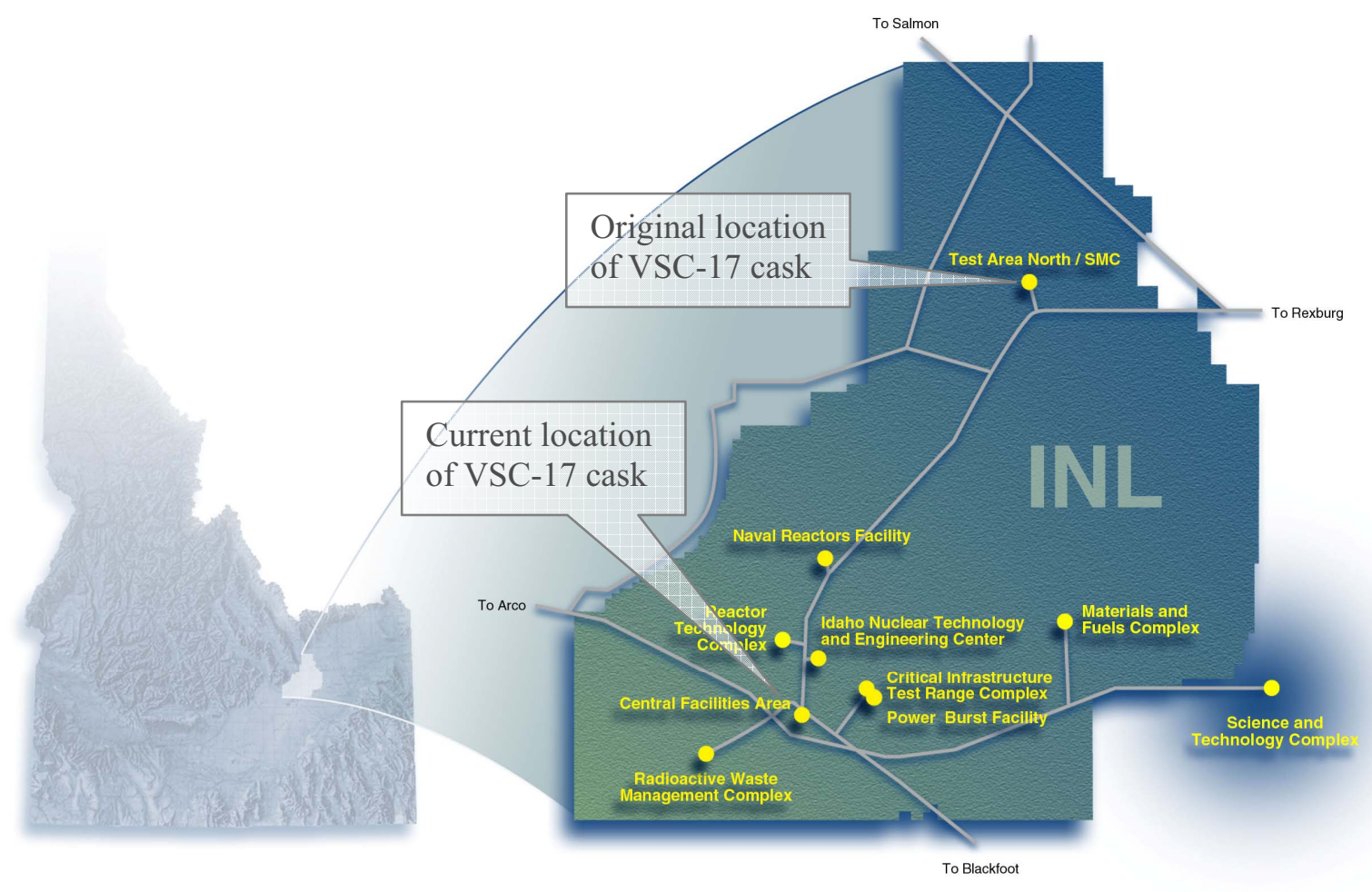

Figure 1. Former and current locations of the VSC-17 cask at the Idaho National Laboratory.

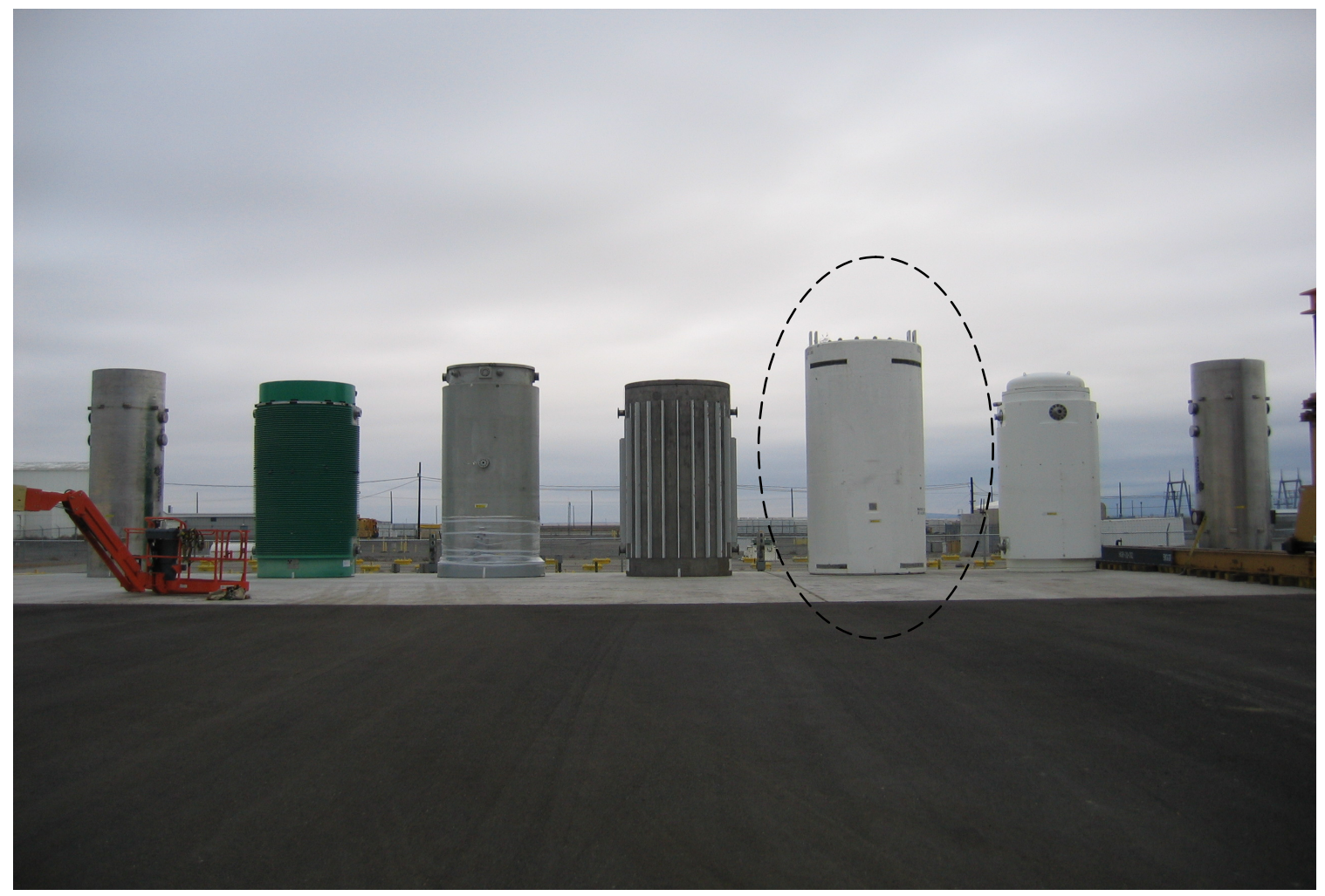

Figure 2. The VSC-17 is the third cask from the right as it is currently stored on the CPP-2707 pad at INTEC. The view of this picture faces to the west. 
The VSC-17 is a concrete-shielded SNF storage cask system that was designed to contain 17 pressurized water reactor (PWR) fuel assemblies. The VSC-17 is a product of the Pacific Sierra Nuclear Company, which was assimilated into the British Nuclear Fuel Limited (BNFL), BNFL Solutions Division. The design is unique in that it was scaled down from the commercially produced VSC-24 units to be compatible with the INL cask mover that was used to move casks from the TAN-791 pad to the TAN 607 Hot Shop. It consists of a central steel container and the multi-element sealed basket (MSB). The MSB is surrounded by a vertical right circular annulus, known as the Ventilated Concrete Cask (VCC), which has a concrete wall thickness of $20 \mathrm{in} .(51 \mathrm{~cm})$. The inner liner of the VCC annulus is A-36 steel that is 3.5 in. $(89 \mathrm{~mm})$ thick, which provides structural support and additional shielding. The annular gap between the steel liner and the MSB is 3 in. $(76 \mathrm{~mm})$. Transfer of decay heat from the MSB occurs by convective airflow through vents in the concrete shielding component. The VSC-17 is one of several casks stored on the INTEC CPP-2707 pad as a demonstration project to show the feasibility of dry storage of commercial SNF. The VCC concrete performance was the focus of this study.

The fuel stored in the VSC-17 came from the Florida Power \& Light Turkey Point and Virginia Electric Power Company Surry Plants. The fuel was originally configured as a $15 \times 15$-rod array in PWR assemblies. The fuel was repackaged as a part of the Dry Rod Consolidation Technology (DRCT) project into canisters that have the same external dimensions as a PWR assembly $(14 \mathrm{ft}[4.3 \mathrm{~m}] \times 8.5 \mathrm{in}$. [21.6 cm] square), but contain 410 rods from derodded assemblies, slightly greater than a two to one consolidation ratio for spent fuel rods. The fuel had a nominal heat load of 398 to $685 \mathrm{~W}$ (26.8 to $30.5 \mathrm{GWd} / \mathrm{tU}$ ) per assembly in 1987 , prior to derodding. ${ }^{1}$

The cask was moved from TAN to the CPP-2707 pad at INTEC in October 2004. The move was executed by heavy-lift specialist subcontractor Shaughnessy \& Company, a division of Bigge Crane and Rigging Company. The cask was lifted approximately $2 \mathrm{ft}(61 \mathrm{~cm})$ using a portable gantry crane system, and placed on a multi-axle lowboy trailer. The loaded trailer was then driven the 18 miles $(29 \mathrm{~km})$ from TAN to INTEC at speeds not to exceed $5 \mathrm{mph}(8 \mathrm{kph})$. Because the road had to be closed during these transports, all road transits occurred at night (Figure 3). The cask was unloaded from the trailer using the same gantry crane system at INTEC and placed on the concrete pad in the same orientation as it was at TAN. The nominal zero reference point was positioned due south at TAN and remains due south at INTEC. Additional pictures of the move are presented on the enclosed compact disc in Appendix A.

INL Packaging and Transportation personnel inspected the cask prior to transport to ensure that it was a tight package and that the tie-downs were in place. No radiological surveys were performed during this inspection. INTEC personnel inspected the cask upon arrival. Radiological survey information of the cask when it was stored at TAN and after the move is in Appendix B.

\subsection{Research and Testing Performed in 2005}

The 2005 testing plan was developed to address questions arising from the analyses performed in 2003 and 2004. The results of the earlier testing showed a step change in the radiation readings at a point approximately $8.2 \mathrm{ft}(2.5 \mathrm{~m})$ above the base of the cask. The cask also showed hot spots at the 52-degree location beneath one of the upper vents. In addition, there were discrepancies in the thermocouple ladder temperature readings that required further investigation. Some research was performed to address questions resulting from the 2004 test. $^{2}$ In addition to the research, nondestructive tests were designed to evaluate the concrete density, thickness, and any potential weak spots to determine the reason for the variable radiation readings. The following tests were performed in 2005. 


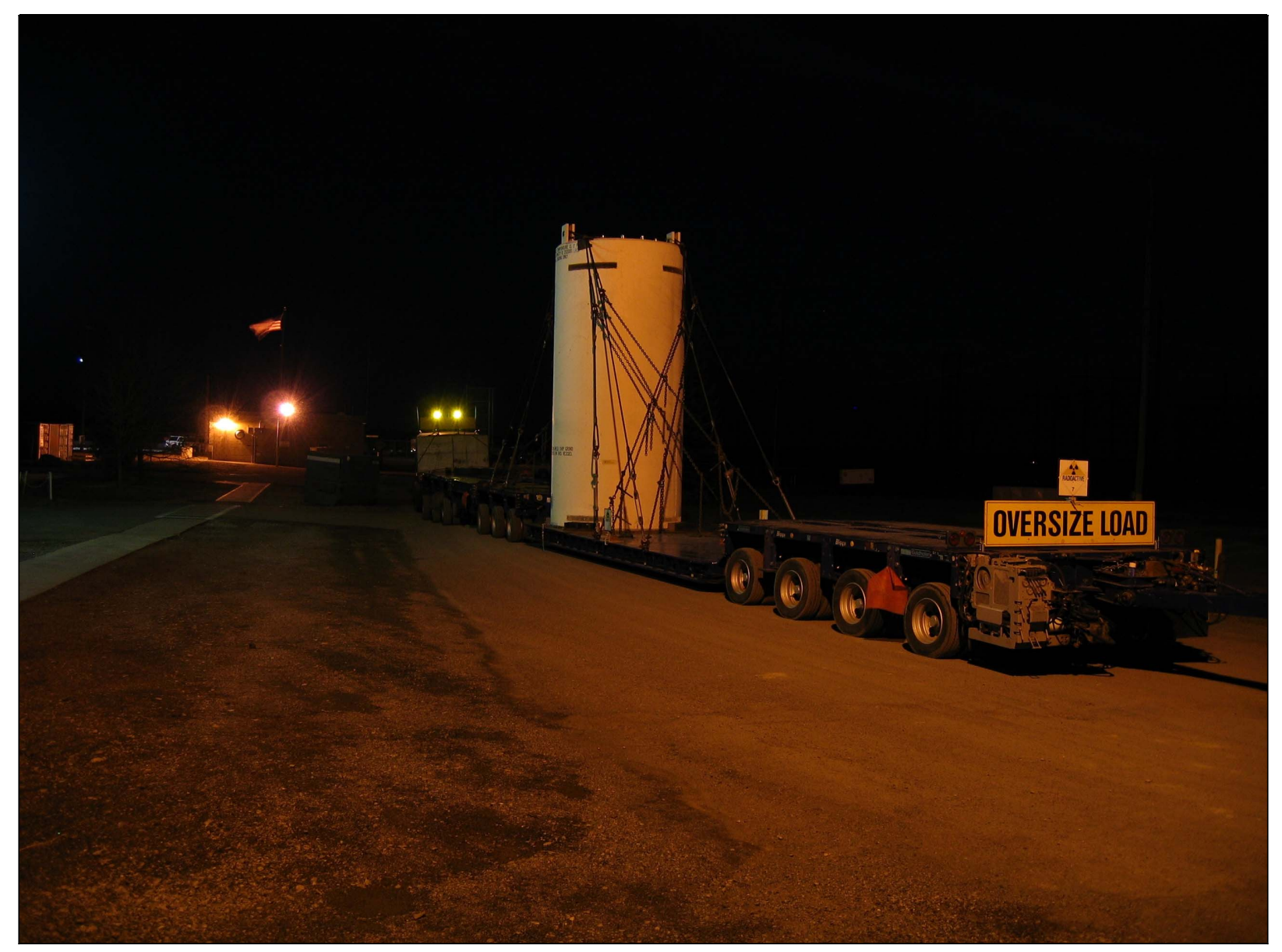

Figure 3. VSC-17 cask transported to INTEC in October 2004 (additional pictures on enclosed CD in Appendix A).

1. Temperature Measurements - performed two different temperature measurements including optical temperature measurements using a thermal imaging camera and a surface temperature survey using a thermocouple ladder to observe surface temperature characteristics.

2. Ultrasonic Testing - tested for crack and deterioration of the cask using a wave propagation test and measured the cask thickness using a reflective wave test.

3. Schmidt Hammer Test - measured the concrete compressive strength of the cask using a nondestructive, hammer rebound test. 


\section{REVIEW AND VERIFICATION OF 2004 WORK}

The 2004 VSC-17 annulus inspection (see Reference 2) raised several questions about the radiation profile of the stored SNF. The loading of the SNF canister was researched to determine if it may be affecting the radiation readings of the VSC-17. The external temperature measurements also showed variability of up to $7^{\circ} \mathrm{F}$. The project team also revisited the process for obtaining surface temperature data from the cask. This section provides the results of further analysis and investigation on these topics and provides clarification to the Reference 2 report.

\subsection{Expected Radiation Profile for the Fuel Stored in the VSC-17 Cask}

The fuel stored in the VSC-17 cask is repackaged PWR fuel of the $15 \times 15$ Westinghouse type from Florida Power \& Light Turkey Point and Virginia Electric Power Company Surry 2 reactors. The repackaging amounted to removing the individual rods from the original end boxes (nozzles) and skeleton and putting 408 rods in a stainless steel shell that has the same dimensions as a PWR assembly containing 204 rods. This repackaging was known as the DRCT project (Reference 1).

Because the stainless steel end boxes and skeleton were removed, the cobalt- 60 activation product associated with those components is not present in the DRCT fuels. The profile exhibited in the gross gamma scan of Assembly D01 (Figure 4) shows the expected high plateau of activity $(100,000$ to $110,000$ counts $/ \mathrm{sec})$ in the middle of the assembly, tapering off to the ends $(50,000$ to 75,000 counts $/ \mathrm{sec})$.

The profile of the activity in the skeleton of Assembly D01 indicates highest activity at the bottom nozzle and peaks at each of the spacer grids. The nozzles and spacer grids were constructed of stainless steel, which became activated with cobalt-60, with proportionally higher activity than the primary fission product cesium-137, as seen in Figure 5. Neither the skeleton profile nor the assembly profile suggests that there is a reason for a step change in activity measured on the exterior of the VSC-17 cask. Because the fuel is packed with minimal void space, the radiation source is maximally shielded by the fuel mass itself. This shielding nullifies source peaks. Elimination of the peaks from cobalt-60 containing spacers yields a relatively smooth curve of activity. If the peaks shown in Figure 5 (skeleton D01) are removed from the curve shown in Figure 4 (D01 assembly), a relatively uniform activity value, which decreases at the ends of the assembly, results.

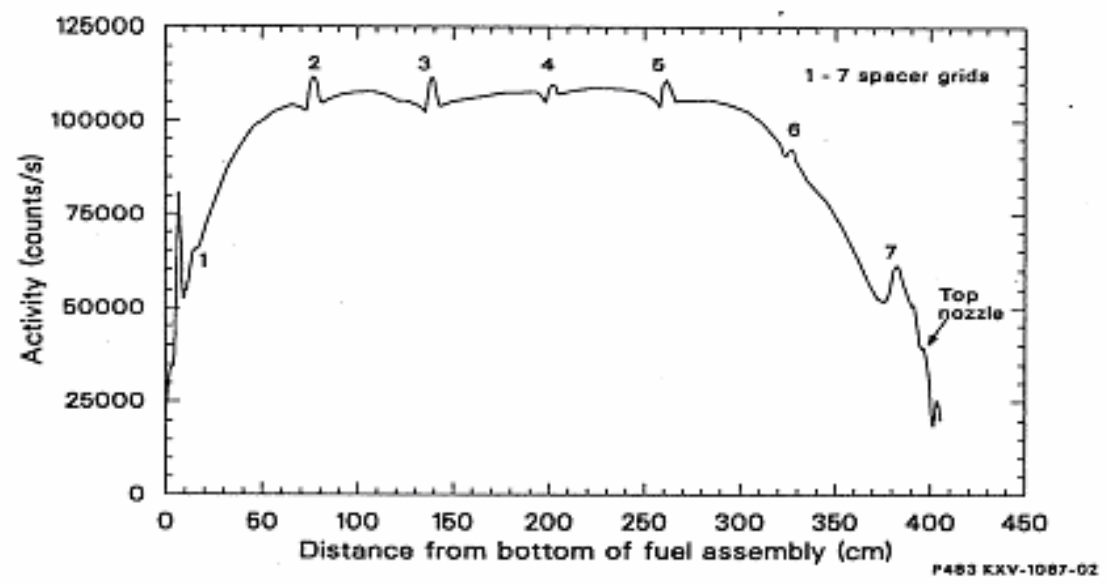

Figure 4. Gross gamma scan of fuel assembly D01 (Reference 1). 


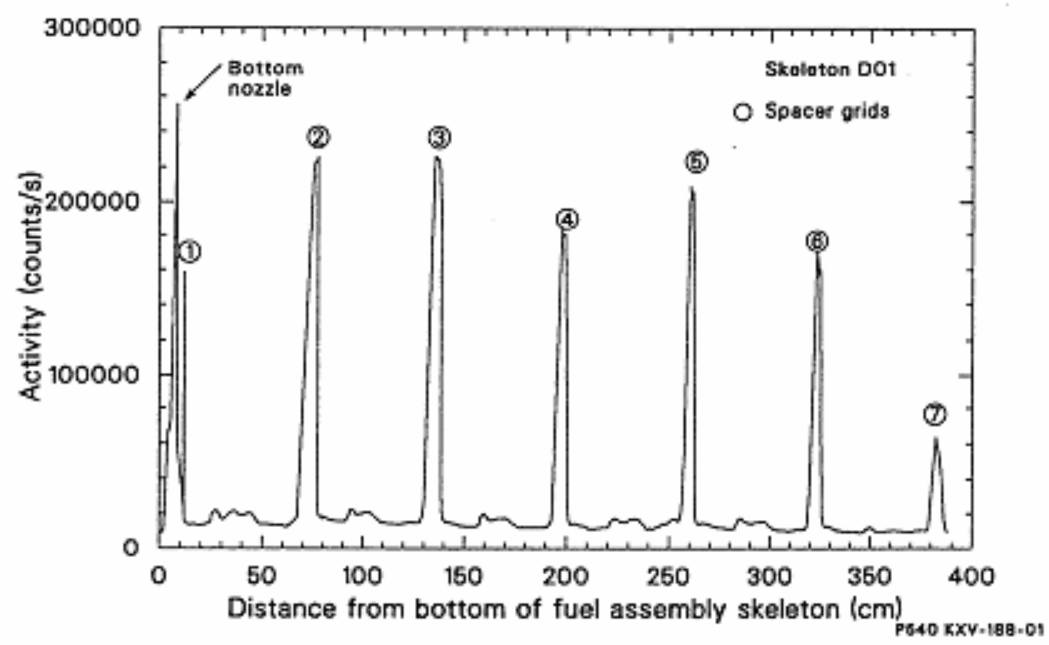

Figure 5. Gross gamma scan of the fuel assembly skeleton D01 (Reference 1).

\subsection{Weather Data for 2004 Temperature Test}

Wind and air temperature data were researched to determine their effects on the 2004 thermocouple ladder readings. Weather observations were provided by the TAN weather station for weather conditions on July 13, 2004, at 12:00 p.m. Mountain Daylight Time. The 24-hour maximum and minimum conditions are as follows:

- $\quad$ Temperature $83.2^{\circ} \mathrm{F}\left(91.3^{\circ} \mathrm{F}\right.$ at $17: 50 ; 53.3^{\circ} \mathrm{F}$ at $\left.6: 05\right)$

- $\quad$ Dew point $33.5^{\circ} \mathrm{F}\left(46.6^{\circ} \mathrm{F}\right.$ at $0: 25 ; 22.5^{\circ} \mathrm{F}$ at $\left.21: 05\right)$

- $\quad$ Relative humidity $17 \%(53 \%$ at $2: 55 ; 9 \%$ at $19: 50)$

- Windspeed $10 \mathrm{mph}$ from east southeast (13 mph at 18:20; $2 \mathrm{mph}$ at 11:15)

- $\quad$ Wind gust $16 \mathrm{mph}(24 \mathrm{mph}$ at 13:00; $3 \mathrm{mph}$ at 7:30)

- $\quad$ Pressure 25.23 in. (25.27 in. at 12:00; 25.15 in. at 20:50)

- $\quad$ Sea level pressure 29.68 in. (29.94 in. at 6:05; 29.54 in. at 19:35)

- $\quad$ Altimeter 30.09 in. (30.15 in. at 12:00; 30.01 in. at 18:50)

- $\quad$ Solar radiation $487.3 \mathrm{~W} / \mathrm{m}^{*} \mathrm{~m}(974.0 \mathrm{~W} / \mathrm{m} * \mathrm{~m}$ at $13: 25 ; 0.0 \mathrm{~W} / \mathrm{m} * \mathrm{~m}$ at $21: 40)$. 
Actual weather conditions on July 13, 2004, during the thermocouple test are listed in Table 1.

Table 1. Tabular listing of weather conditions for July 12, 2004, from 11:00 a.m. to 12:00 p.m.

\begin{tabular}{|c|c|c|c|c|c|c|c|c|}
\hline $\begin{array}{c}\text { Time } \\
(\mathrm{MDT}) \\
5 \mathrm{~min}\end{array}$ & $\begin{array}{c}\text { Temperature } \\
\left({ }^{\circ} \mathrm{F}\right)\end{array}$ & $\begin{array}{c}\text { Dew } \\
\text { Point } \\
\left({ }^{\circ} \mathrm{F}\right)\end{array}$ & $\begin{array}{c}\text { Relative } \\
\text { Humidity }\end{array}$ & $\begin{array}{c}\text { Windspeed } \\
(\mathrm{mph})\end{array}$ & $\begin{array}{c}\text { Wind } \\
\text { Gust } \\
(\mathrm{mph})\end{array}$ & $\begin{array}{c}\text { Wind } \\
\text { Direction }\end{array}$ & $\begin{array}{c}\text { Pressure } \\
(\mathrm{in} .)\end{array}$ & $\begin{array}{c}\text { Solar } \\
\text { Radiation } \\
\left(\mathrm{W} / \mathrm{m}^{*} \mathrm{~m}\right)\end{array}$ \\
\hline $12: 00$ & 83.2 & 33.5 & 17 & 10 & 16 & ESE & 25.23 & 487.3 \\
\hline $11: 55$ & 82.9 & 33.4 & 17 & 9 & 13 & E & 25.23 & 451.2 \\
\hline $11: 50$ & 82.9 & 33.9 & 17 & 8 & 13 & E & 25.23 & 321 \\
\hline $11: 45$ & 83.5 & 33.6 & 17 & 8 & 11 & ESE & 25.23 & 568.2 \\
\hline $11: 40$ & 82.5 & 34 & 18 & 5 & 8 & ESE & 25.23 & 537.6 \\
\hline $11: 35$ & 82 & 34.3 & 18 & 5 & 8 & SE & 25.23 & 832 \\
\hline $11: 30$ & 81.6 & 34.4 & 18 & 5 & 7 & ESE & 25.23 & 296.3 \\
\hline $11: 25$ & 81.2 & 34.2 & 18 & 3 & 7 & ESE & 25.24 & 353.6 \\
\hline $11: 20$ & 80.7 & 34.6 & 19 & 4 & 6 & ESE & 25.23 & 405.8 \\
\hline $11: 15$ & 80.6 & 34.6 & 19 & 2 & 4 & N & 25.24 & 325.5 \\
\hline $11: 10$ & 82.4 & 35.3 & 18 & 6 & 9 & NE & 25.24 & 842 \\
\hline $11: 00$ & 79.6 & 35.2 & 20 & 4 & 6 & N & 25.24 & 634.8 \\
\hline
\end{tabular}

The data in Table 1 show that the thermocouple data taken in 2004 suffer from substantial conductive and convective-caused variability that is not the result of surface temperature changes on the cask or temperature variability in the atmosphere.

\subsection{Temperature Stability Testing}

The data acquired by use of a series of thermocouples mounted on an aluminum mast showed substantial $\left(5\right.$ to $\left.7^{\circ} \mathrm{F}\right)$ variation during the measurements made in July 2004 . This design used a support structure constructed of 2-in. (5-cm) aluminum angle to support 17 thermocouples used to measure variations along the height of the cask wall. The Type $J$ thermocouples were mounted on adhesive felt pads to prevent contact with the aluminum angle. The project team noted during data analysis that the values for 0/360 degrees were inconsistent, showing lower temperatures and a different gradient an hour following the initial measurement. The project team immediately began to determine the source of the inconsistency. Stability and repeatability testing were performed to establish data acquisition error versus system error.

In later testing of this thermocouple rake arrangement, the project team noted a lesser but consistent $\left(3\right.$ to $\left.5^{\circ} \mathrm{F}\right)$ variation under essentially static conditions (i.e., the system was laid against a concrete floor inside the remote operations building). This was clearly a problem, because there was neither substantial airflow nor radiant heating to affect the system. This variation is believed to be due to convection and conduction around points of incomplete thermal insulation at the terminals and leads of the thermocouples. Conduction was occurring as heat was transferred away along the aluminum mast. 
The project team removed the thermocouples from the aluminum support and mounted them on a square fiberglass tube. The individual thermocouples and leads were insulated by embedding them in closed cell foam rubber. Further isolation and insulation was performed by installing the terminal covers on the data acquisition unit and positioning the unit in a box surrounded by polystyrene foam. The result achieved by this modification is an improvement in data stability with a consistency level of 1.5 to $2^{\circ} \mathrm{F}$ (for measurements taken when the thermocouple rake was laid on the floor in the remote operations laboratory) (Figure 6). When measuring the temperature of the outside wall of the laboratory building (Figure 7), the largest max-min delta was $4^{\circ} \mathrm{F}$. Temperature comparison using a Raytek Minitemp MT4 noncontact infrared thermometer showed consistency within $0.1^{\circ} \mathrm{F}$ and confirmed that variation in the temperature of the laboratory wall due to wind convection was indicated by both instruments. The building wall is nominally 28 -gauge corrugated steel sheet, which loses and gains heat rapidly. Data from the exterior wall test are contained in attached file 01-c_appendtest4-13-05.xls in Appendix C. Data from the static test on the interior floor are contained in attached file 02-c_appendtctest 2 .xls also in Appendix C.

\subsection{Measurement Using Bare Thermocouple to Measure Annulus Temperature}

Measurement of the annulus temperature in July of 2004 was done with a bare thermocouple attached to extend beyond an AMP-100 radiation detector. No secondary weight was used to lower the thermocouple into the annulus. No device was used to position the thermocouple a consistent distance between the thermocouple and the shield wall and basket wall due to concerns that the detector and thermocouple would become entangled inside the annulus. As with the initial temperature rake measurements, the terminals at the data acquisition unit were not covered to prevent temperature variation due to wind-caused convection. However, because the thermocouple was not exposed to the highly variable wind conditions that the external thermocouples were, the variability of the measurements was not as large.

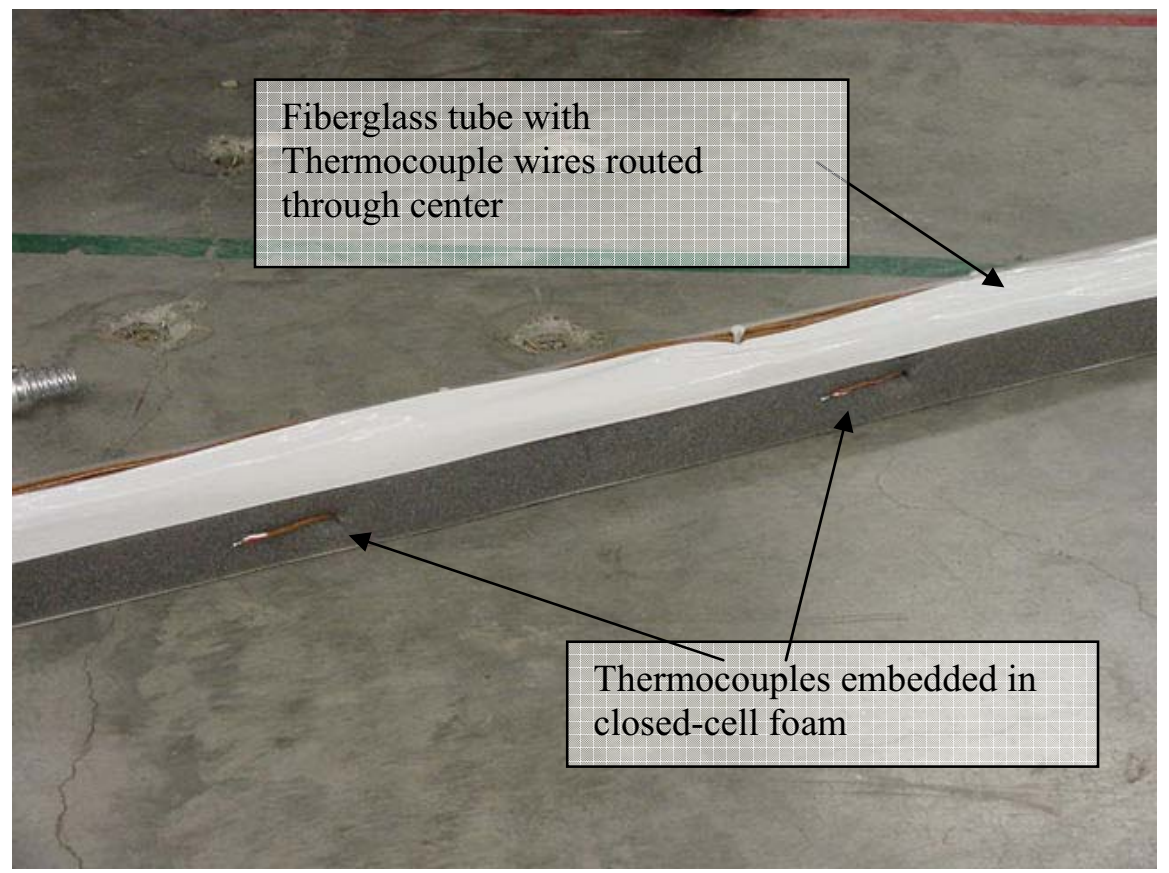

Figure 6. Insulated thermocouple configuration on fiberglass pole. 


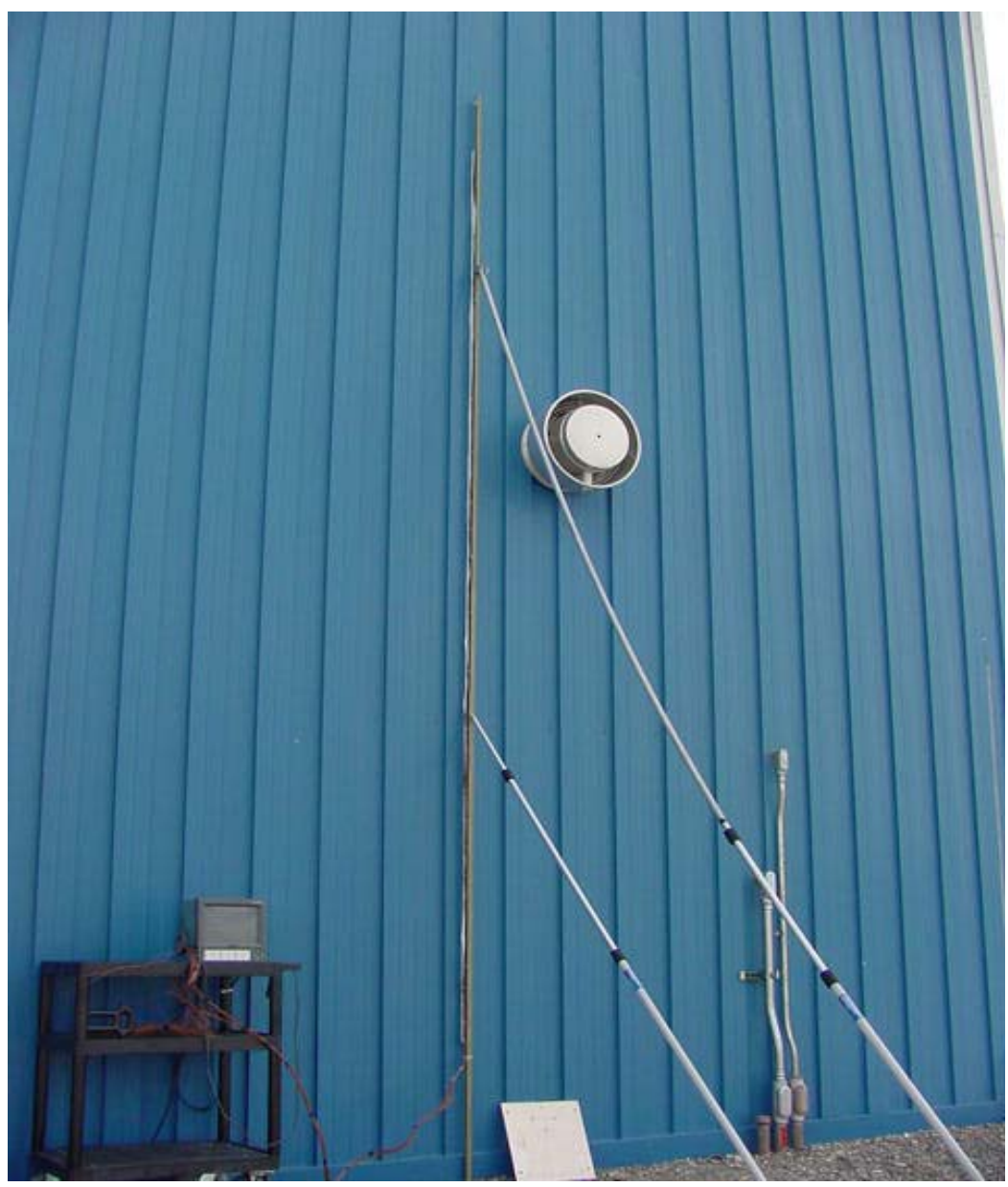

Figure 7. Laboratory building wall test of insulated thermocouple rake. 


\section{2005 NONDESTRUCTIVE ANALYSES}

\subsection{Temperature Measurements}

\subsubsection{Insulated Thermocouple Measurements}

Thermocouple measurements were performed at nominal 8 -in. $(20-\mathrm{cm})$ radial positions, which correspond to approximately 8.8 -degree intervals $(329$-in. cask circumference $/ 8$ in. per interval $=$ 41 intervals; 360 degrees $/ 41$ intervals $=8.78$ degrees/interval). This is an approximation carried over from the initial (2003) testing that does not take into consideration the fact that the noninteger circumferential length does not divide evenly into 8.8-degree increments, leaving the final interval less than $8 \mathrm{in}$. The counterclockwise progression of increments is also an artifact of the 2003 testing during which the instrument cables would not have reached all locations if the sequence had been performed clockwise. The zero point corresponds to the south lifting lug, and 90 degrees corresponds to the nameplate position on the cask. The cask orientation has not been changed as a result of the move from TAN-791 to CPP-2707.

Thermocouple testing was performed on July 27, 2005, from 10:56 to 13:59 MDT. The data acquisition system recorded values every second and reported the maximum and minimum value for that period. Data were taken as three sets of 30 -second periods for each radial position. The test was performed operationally as shown in Figure 8. This image shows the thermocouple rake being supported against the cask surface by extension poles.

Since being moved to the CPP-2707 pad, the cask was fitted with a structure that supports an electrical conduit to connect wires to the intact internal thermocouples that are accessible through the top weather cover. This conduit support structure consists of a square tube frame that is attached to the cask with stainless steel straps. The structure and the straps extend out sufficiently to interfere with making thermocouple contact readings on the west side of the cask. The portion of the cask that is effectively obstructed is between 210 degrees to 340 degrees. Therefore, rather than taking 41 radial measurements, only 27 were accessible. The frame is visible in Figure 9.

As discussed in Section 2.3, the modified thermocouple rake included mounting the thermocouples in closed cell foam and surrounding the support mast with additional insulation. A cross section of the rake is shown in Figure 10. The closed cell foam in which the thermocouple is embedded conforms to surface variations and provides spring pressure to maintain contact with the surface. The external closed cell foam provides an additional barrier to airflow between the thermocouple and the surface.

One thermocouple located at the top of the mast and a second one located approximately $6 \mathrm{ft}$ $(180 \mathrm{~cm})$ from the ground were not embedded in foam or shielded from the sun or wind. The temperature data from these two thermocouples showed a substantial variation from the temperature data obtained from the insulated thermocouples as well as the ambient temperatures recorded at the nearest weather station located at the INL Reactor Technology Complex. The temperature variance is most notable for the measurements obtained when the ambient thermocouples were in the sun. Because of the low mass of the thermocouple, it is suspected that radiant heating from solar input created the 10 to 30 -degree offset between the thermocouples contacting the cask surface and the ambient exposed thermocouples.

The data on the CD in Appendix D, cmptempvsc-17 05r1.xls, include a calculated mean value between the maximum and minimum for each recorded reading. Average thermocouple rake readings are shown in Table 2. 
Graphical representation of the temperature data is shown in Figures 11 and 12. The data are shown for the two sections that cover the areas measured. Temperatures shift to higher values as external ambient temperature increases. The data shown in the graphical representation do not include the ambient thermocouples from positions 17 and 18.

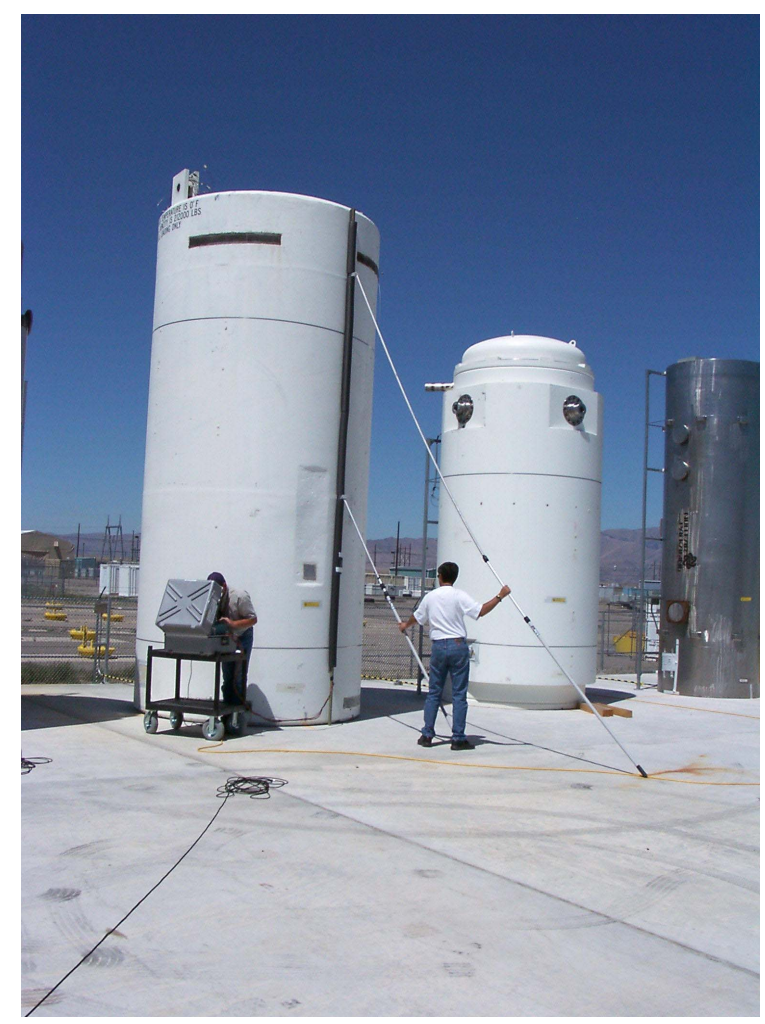

Figure 8. Surface temperature measurements were obtained using a thermocouple rake.

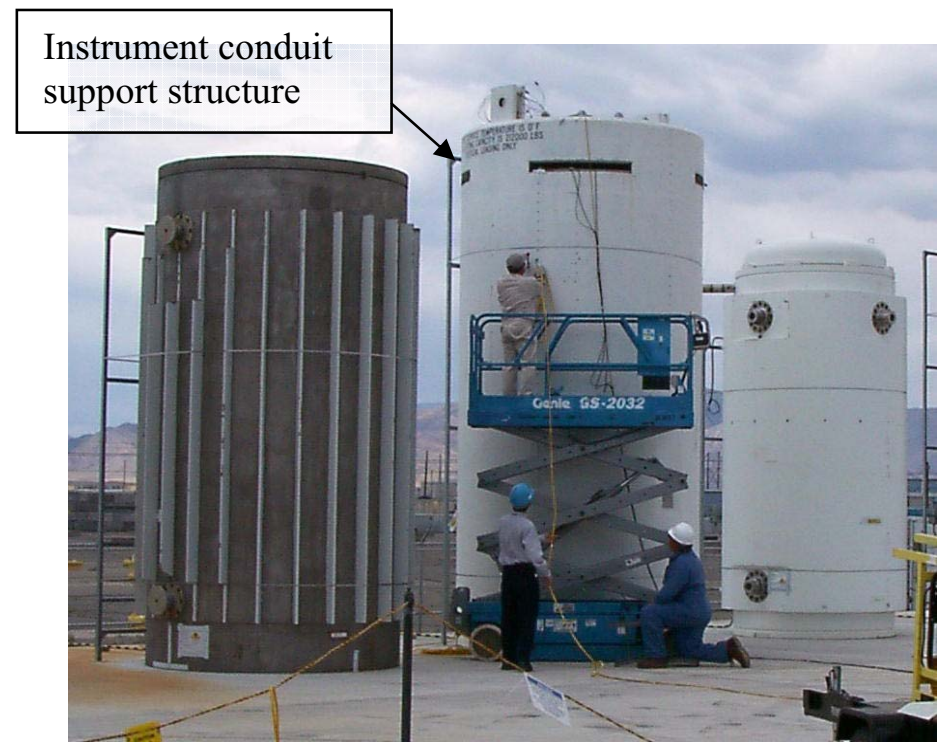

Figure 9. Electrical conduit is visible from behind the VSC-17 cask, which prevented obtaining surface temperature measurements on the west side of the cask. 


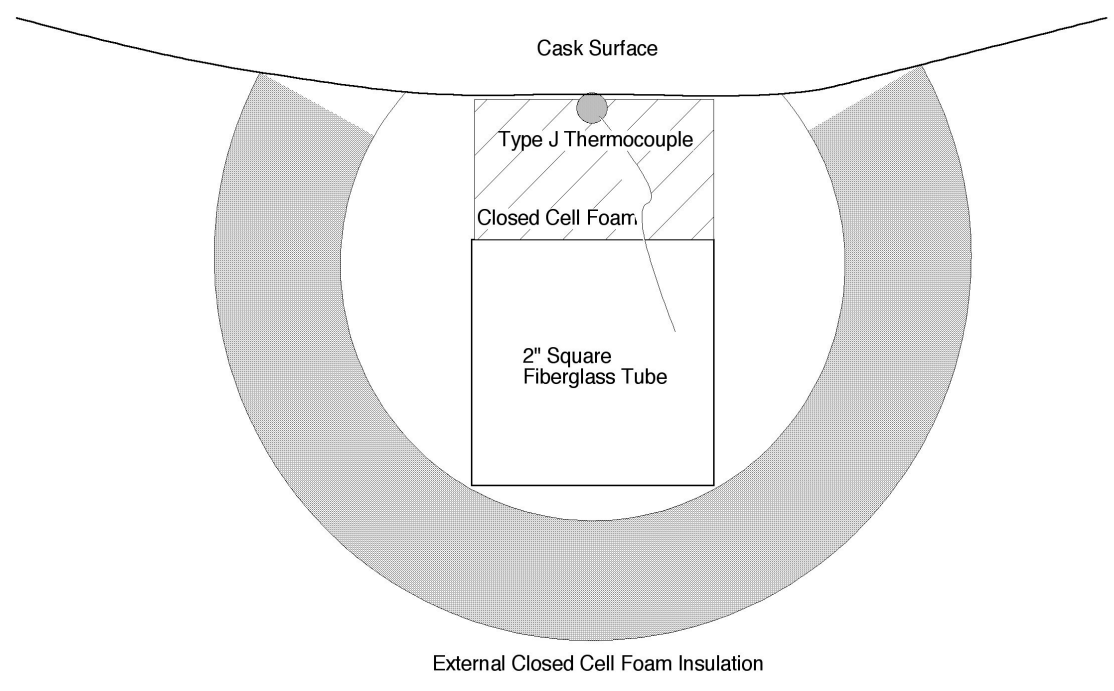

Figure 10. Cross section of thermocouple rake.

Table 2. Average thermocouple rake measurements for 2005.

\begin{tabular}{|l|c|}
\hline & Degrees \\
& $(\mathrm{F})$ \\
\hline Radial Average Temperature & 87.787 \\
\hline Radial Rake Maximum Average & 91.797 \\
\hline Radial Rake Minimum Average & 83.483 \\
\hline Radial Rake Max-Min Average Delta & 8.314 \\
\hline Standard Deviation & 0.478 \\
\hline
\end{tabular}




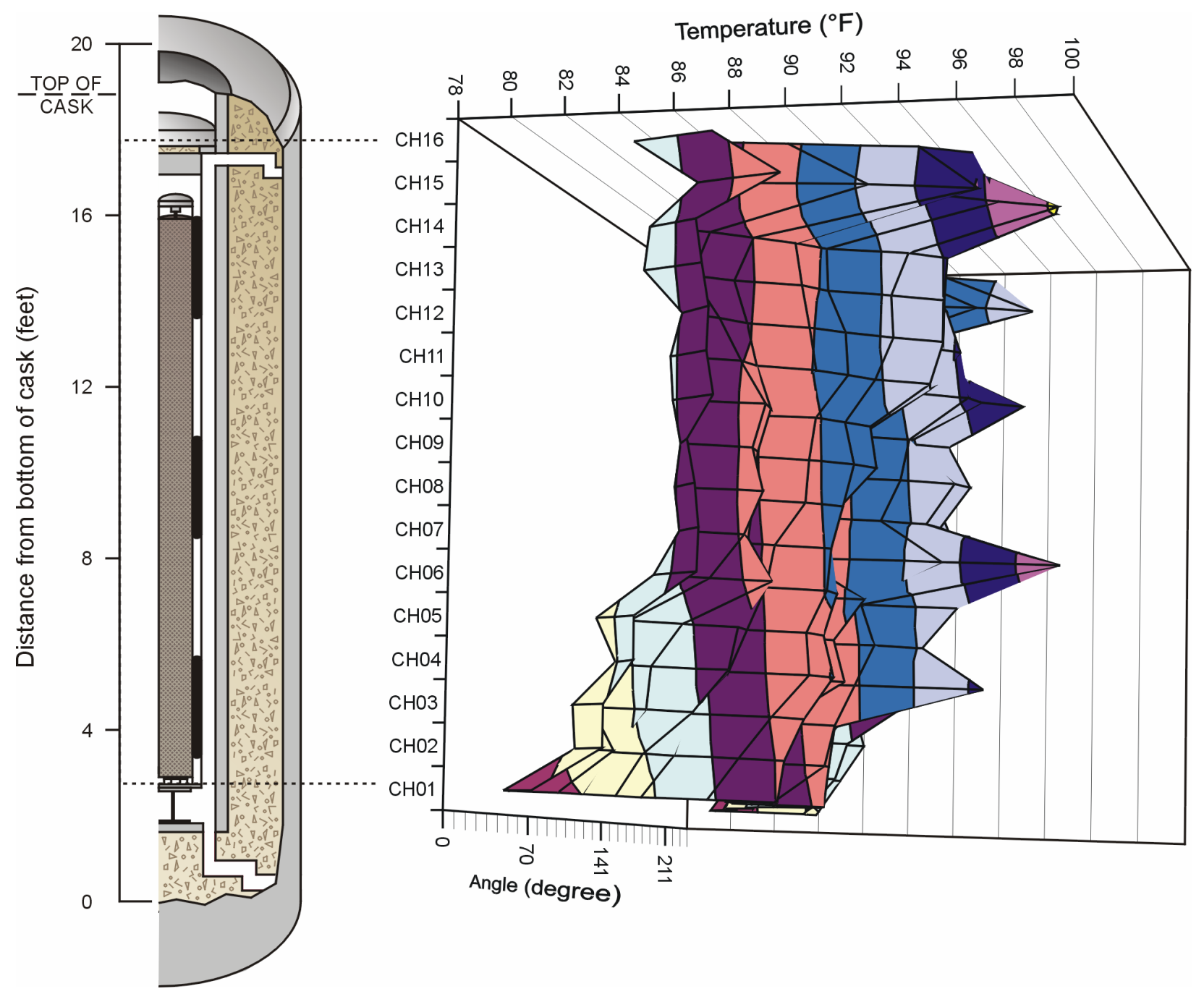

Figure 11. Temperature readings for 0 degrees to 210 degrees. 


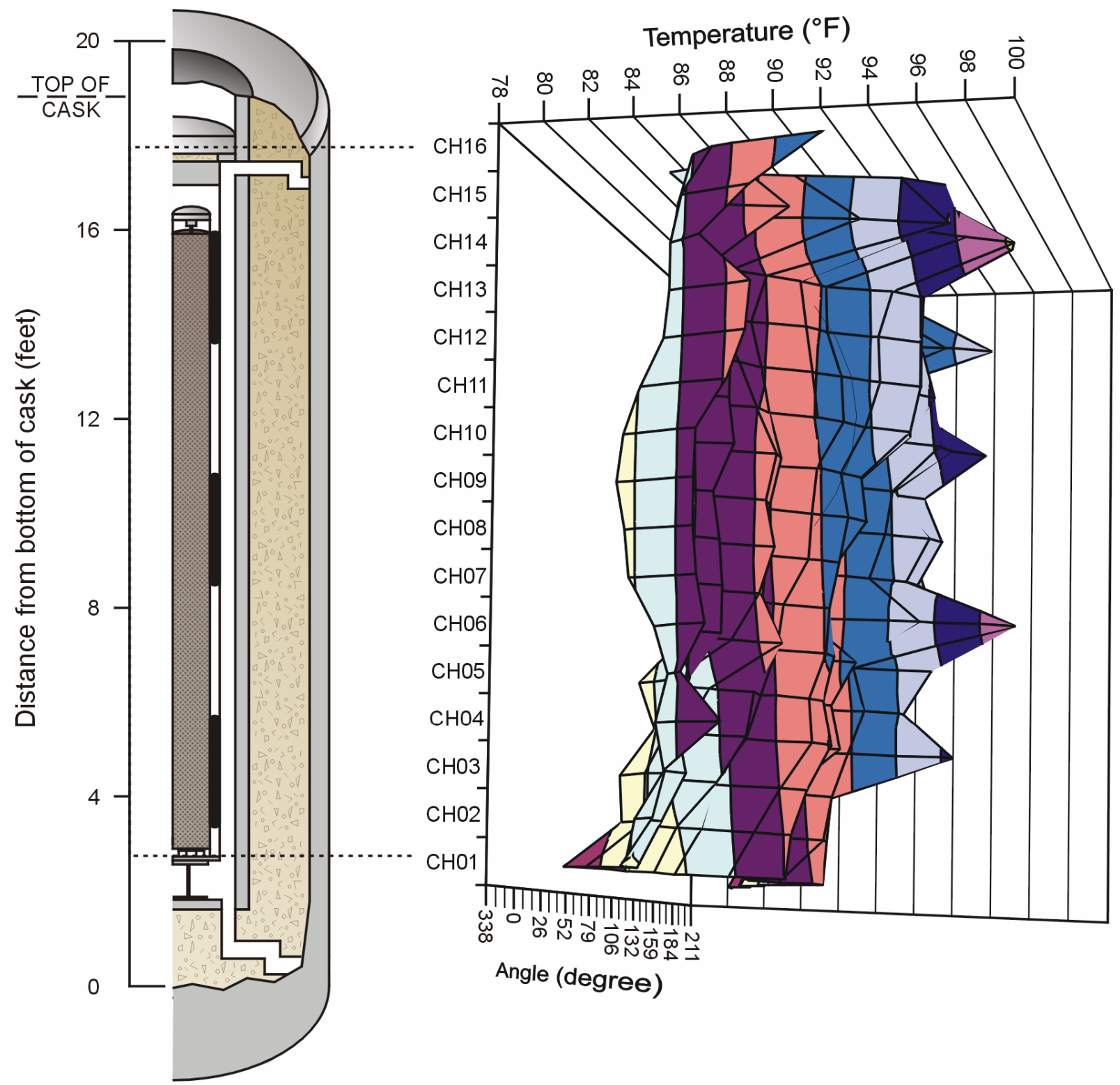

Figure 12. Surface temperature data from the radial 340 degrees through 210 degrees locations.

\subsubsection{Optical Thermal Measurements}

The following image and data were produced using a FLIR Systems digital thermal imaging unit. The person in the center of the Figure 13 image is holding the thermocouple rake against the cask at the nominal 90-degree position.

Emissivity has been adjusted to correlate the indicated value at SP02 $\left(88.9^{\circ} \mathrm{F}\right)$ with the measured value reported on the second 30 -second data segment of Channel 05 of the thermocouple rake.

The image in Figure 14 provides a reference with an unadjusted emissivity value and lower ambient temperature. This shows that the external temperature of the cask varies consistently with atmospheric conditions. 


\begin{tabular}{|l|l|}
\hline IR-Image File Name & Date \\
\hline & \\
\hline
\end{tabular}

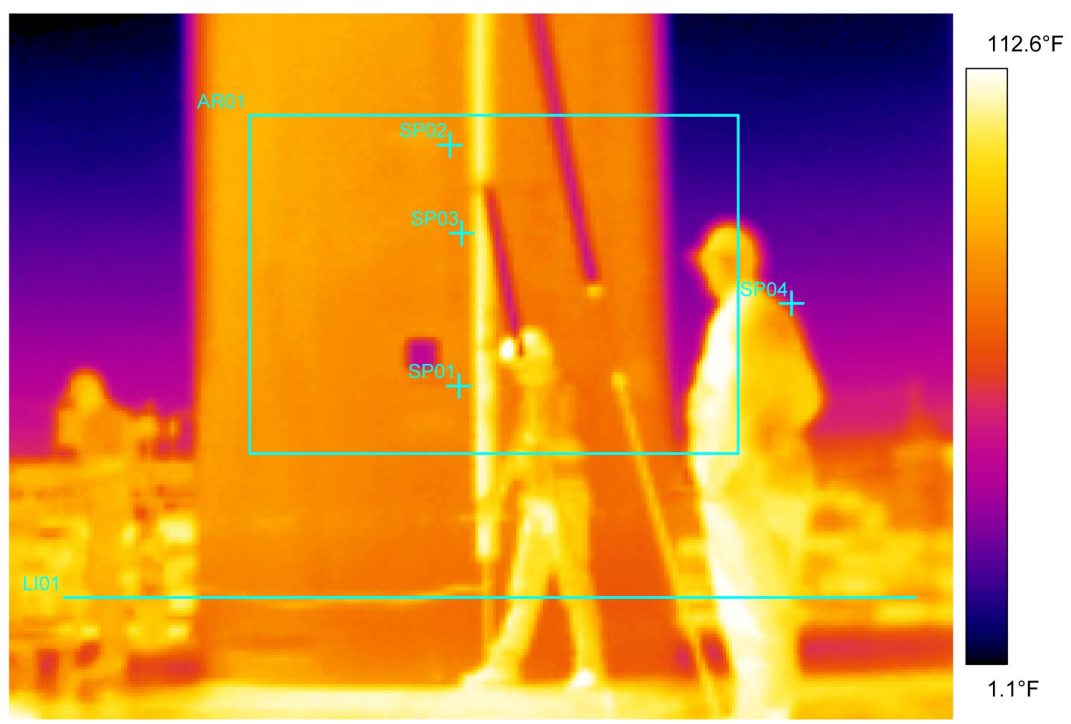

\begin{tabular}{|l|l|}
\hline Comments: \\
\hline Section: & \\
\hline Equipment: & \\
\hline Additional Info:: & \\
\hline Fault: & \\
\hline Recommendation: & \\
\hline
\end{tabular}

\begin{tabular}{|l|l|l|}
\hline IR information & Value & \\
\hline Date of creation & $7 / 27 / 2005$ & - \\
\hline Time of creation & $1: 39: 53 \mathrm{PM}$ & - \\
\hline Object parameter & Value & \\
\hline Emissivity & 0.95 & - \\
\hline Object distance & $6.6 \mathrm{ft}$ & - \\
\hline Ambient temperature & $68.0^{\circ} \mathrm{F}$ & - \\
\hline Atmospheric & $68.0^{\circ} \mathrm{F}$ & - \\
\hline Transmission & 0.99 & - \\
\hline Label & Value & Diff \\
\hline SP01 & $87.4^{\circ} \mathrm{F}$ & $19.4^{\circ} \mathrm{F}$ \\
\hline SP02 & $88.9^{\circ} \mathrm{F}$ & $20.9^{\circ} \mathrm{F}$ \\
\hline SP03 & $87.7^{\circ} \mathrm{F}$ & $19.7^{\circ} \mathrm{F}$ \\
\hline SP04 & $54.9^{\circ} \mathrm{F}$ & $-13.1^{\circ} \mathrm{F}$ \\
\hline LI01: $\max$ & $115.6^{\circ} \mathrm{F}$ & $47.6^{\circ} \mathrm{F}$ \\
\hline LI01: $\min$ & $81.4^{\circ} \mathrm{F}$ & $13.4^{\circ} \mathrm{F}$ \\
\hline
\end{tabular}

\section{Description}

Place for individual description.

Figure 13. Thermocouple rake measurements and corresponding adjusted emissivity (image by Jerry Bingham). 


\begin{tabular}{|l|l|}
\hline IR-Image File Name & Date \\
\hline CPP CASKS 01 & $5 / 19 / 2005$ \\
\hline
\end{tabular}

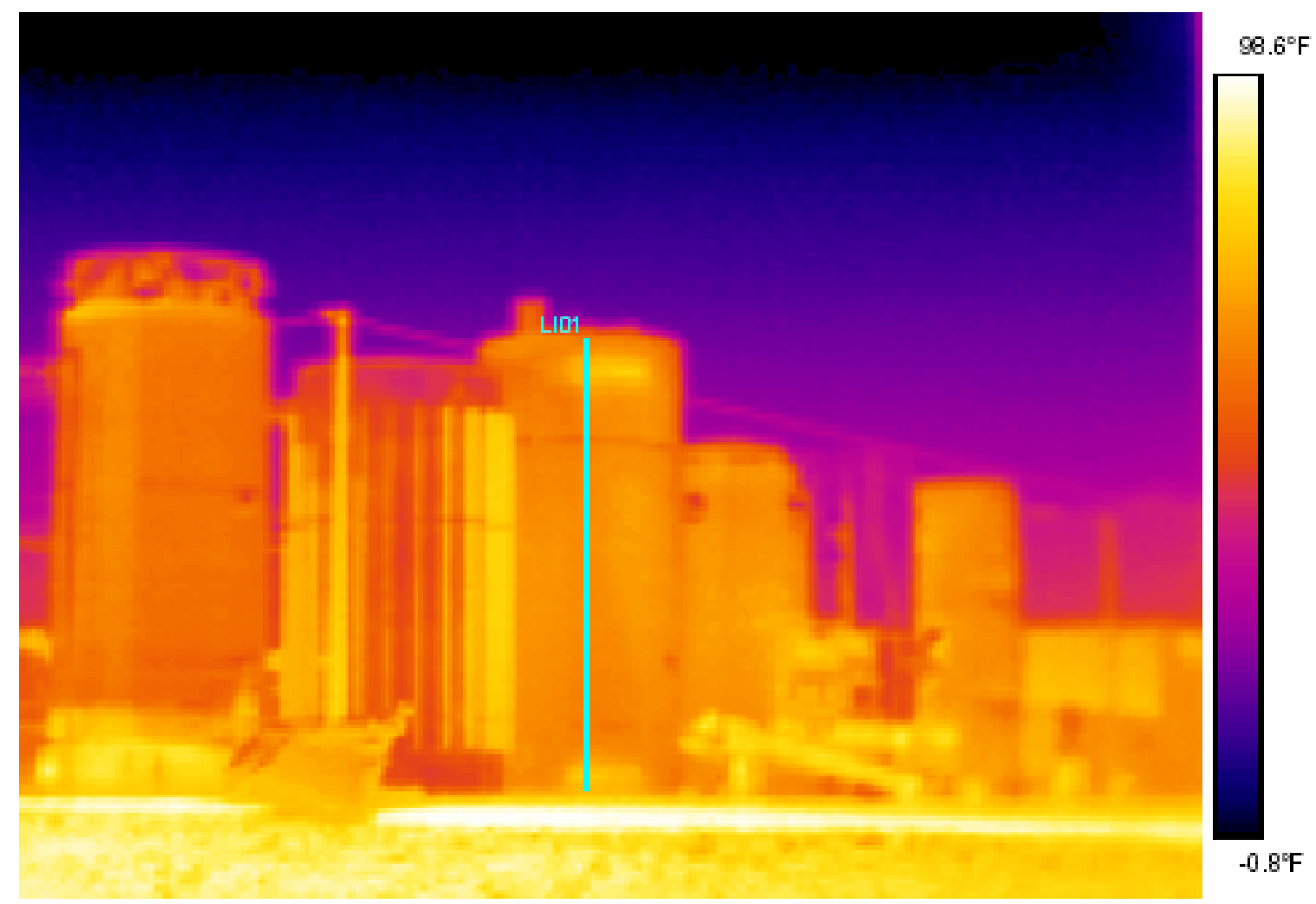

\begin{tabular}{|l|l|}
\hline Comments: \\
\hline Section: & \\
\hline Equipment: & INTEC CASK \\
\hline Additional Info: & \\
\hline Fault: & \\
\hline Recommendation: & \\
\hline
\end{tabular}

\begin{tabular}{|c|c|c|}
\hline IR information & Value & \\
\hline Date of creation & $5 / 79 / 2005$ & \\
\hline Time of creation & 3:07:50सM & \\
\hline Object parameter & Value & \\
\hline Emissivity & 0.95 & \\
\hline Object distance & $50.0 \mathrm{ft}$ & \\
\hline Ambient temperature & $88.0^{\circ} \mathrm{F}$ & \\
\hline Atmospheric & $88.0^{\circ} \mathrm{F}$ & \\
\hline Transmission & 0.98 & \\
\hline Label & Value & Diff \\
\hline L01: $\max$ & $76.9^{\circ} \mathrm{F}$ & $8.9^{\circ} \mathrm{F}$ \\
\hline L101: $\min$ & $56.2^{\circ} \mathrm{F}$ & $1.8^{\circ}$ \\
\hline
\end{tabular}

Figure 14. Infrared image of casks taken at INTEC (photo by Darrell Johnson). 


\subsection{Weather Data for 2005 Temperature Testing}

Tables 3 and 4 show the past weather conditions for weather station EAC (Test Reactor Area, currently the Reactor Technology Complex) at INL during the period in which the temperature data were measured for VSC-17. These data are supplied by the National Oceanic and Atmospheric Administration Field Research Division. The average ambient temperature over this testing period was $80.3^{\circ} \mathrm{F}$.

Table 3. Weather conditions during the July 27, 2005, period in which temperature data were gathered on the surface of the VSC-17 cask.

\begin{tabular}{|l|l|c|c|}
\hline \multicolumn{4}{|c|}{ Weather Conditions on July 27, 2005, 14:00 MDT } \\
\hline & \multicolumn{1}{|c|}{$14: 00$} & $\begin{array}{c}24 \text { Hour } \\
\text { (Max) }\end{array}$ & $\begin{array}{c}24 \text { Hour } \\
\text { (Min) }\end{array}$ \\
\hline Temperature & $85.9^{\circ} \mathrm{F}$ & 85.9 at $14: 00$ & 41.2 at $6: 45$ \\
\hline Dew Point & $25.6^{\circ} \mathrm{F}$ & 34.1 at $8: 05$ & 17.7 at $2: 50$ \\
\hline Wet Bulb Temperature & $54.5^{\circ} \mathrm{F}$ & 54.7 at $13: 45$ & 32.7 at $3: 35$ \\
\hline Relative Humidity & $11 \%$ & 51 at $6: 35$ & 11 at $14: 00$ \\
\hline Windspeed & $13 \mathrm{mph}$ from SW & 17 at $20: 40$ & 1 at $3: 25$ \\
\hline Wind Gust & $19 \mathrm{mph}$ & 24 at $12: 50$ & 2 at $3: 25$ \\
\hline
\end{tabular}

Table 4. Tabular listing: July 27, 2005-11:00 through July 27, 2005, 14:00 MDT.

\begin{tabular}{|c|c|c|c|c|c|c|c|}
\hline $\begin{array}{c}\text { Time } \\
(\mathrm{MDT})\end{array}$ & $\begin{array}{c}\text { Temperature } \\
\left({ }^{\circ} \mathrm{F}\right)\end{array}$ & $\begin{array}{c}\text { Dew } \\
\text { Point } \\
\left({ }^{\circ} \mathrm{F}\right)\end{array}$ & $\begin{array}{c}\text { Wet Bulb } \\
\text { Temperature } \\
\left({ }^{\circ} \mathrm{F}\right)\end{array}$ & $\begin{array}{c}\text { Relative } \\
\text { Humidity } \\
(\%)\end{array}$ & $\begin{array}{c}\text { Wind } \\
\text { Speed } \\
(\mathrm{mph})\end{array}$ & $\begin{array}{c}\text { Wind } \\
\text { Gust } \\
(\mathrm{mph})\end{array}$ & $\begin{array}{c}\text { Wind } \\
\text { Direction }\end{array}$ \\
\hline $14: 30$ & 86.7 & 24.9 & 54.6 & 11 & 13 & 18 & SW \\
\hline $14: 25$ & 86.6 & 24.5 & 54.5 & 10 & 15 & 24 & SSW \\
\hline $14: 20$ & 86.5 & 25.2 & 54.6 & 11 & 13 & 21 & SSW \\
\hline $14: 15$ & 86 & 25.2 & 54.5 & 11 & 10 & 14 & SSW \\
\hline $14: 10$ & 85.3 & 24.5 & 54 & 11 & 10 & 16 & SSW \\
\hline $14: 05$ & 85.2 & 24.3 & 53.9 & 11 & 10 & 16 & SW \\
\hline $14: 00$ & 85.9 & 25.6 & 54.5 & 11 & 13 & 19 & SW \\
\hline $13: 55$ & 85.4 & 26.4 & 54.5 & 12 & 11 & 15 & SW \\
\hline $13: 50$ & 84.6 & 27.4 & 54.4 & 13 & 5 & 10 & SSW \\
\hline $13: 45$ & 84.8 & 28.2 & 54.7 & 13 & 10 & 19 & SSW \\
\hline $13: 40$ & 83.5 & 28.4 & 54.3 & 14 & 10 & 17 & WSW \\
\hline $13: 35$ & 82.5 & 27.9 & 53.8 & 14 & 7 & 12 & WSW \\
\hline $13: 30$ & 83.8 & 28.8 & 54.5 & 14 & 12 & 20 & WSW \\
\hline $13: 25$ & 83.9 & 29.3 & 54.6 & 14 & 6 & 16 & SSW \\
\hline $13: 20$ & 84.1 & 29.1 & 54.7 & 14 & 9 & 14 & WSW \\
\hline $13: 15$ & 83 & 29.2 & 54.3 & 14 & 10 & 16 & WSW \\
\hline $13: 10$ & 82.5 & 29.5 & 54.2 & 15 & 9 & 17 & WSW \\
\hline $13: 05$ & 82.3 & 30.1 & 54.3 & 15 & 10 & 17 & WSW \\
\hline $13: 00$ & 82.3 & 28.9 & 53.9 & 14 & 11 & 15 & WSW \\
\hline
\end{tabular}


Table 4. (continued).

\begin{tabular}{|c|c|c|c|c|c|c|c|}
\hline $\begin{array}{l}\text { Time } \\
(\mathrm{MDT})\end{array}$ & $\begin{array}{c}\text { Temperature } \\
\left({ }^{\circ} \mathrm{F}\right)\end{array}$ & $\begin{array}{l}\text { Dew } \\
\text { Point } \\
\left({ }^{\circ} \mathrm{F}\right)\end{array}$ & $\begin{array}{c}\text { Wet Bulb } \\
\text { Temperature } \\
\left({ }^{\circ} \mathrm{F}\right)\end{array}$ & $\begin{array}{c}\text { Relative } \\
\text { Humidity } \\
(\%)\end{array}$ & $\begin{array}{l}\text { Wind } \\
\text { Speed } \\
(\mathrm{mph})\end{array}$ & $\begin{array}{l}\text { Wind } \\
\text { Gust } \\
\text { (mph) }\end{array}$ & $\begin{array}{c}\text { Wind } \\
\text { Direction }\end{array}$ \\
\hline $12: 55$ & 81.7 & 28.9 & 53.7 & 15 & 10 & 17 & SW \\
\hline $12: 50$ & 81.7 & 28.1 & 53.5 & 14 & 9 & 24 & SW \\
\hline $12: 45$ & 81.5 & 29.8 & 53.9 & 15 & 11 & 15 & WSW \\
\hline $12: 40$ & 81 & 30.5 & 53.9 & 16 & 11 & 15 & SW \\
\hline $12: 35$ & 80.8 & 30.7 & 53.9 & 16 & 10 & 20 & SW \\
\hline $12: 15$ & 77.7 & 30.8 & 52.7 & 18 & 5 & 10 & WSW \\
\hline $12: 10$ & 78.1 & 30.7 & 52.8 & 18 & 6 & 13 & SW \\
\hline $12: 05$ & 78 & 30.5 & 52.7 & 18 & 5 & 9 & SSE \\
\hline $12: 00$ & 77.3 & 30.2 & 52.4 & 18 & 5 & 10 & SSW \\
\hline $11: 55$ & 77.8 & 30.2 & 52.6 & 18 & 7 & 10 & $\mathrm{~S}$ \\
\hline $11: 50$ & 75.9 & 30 & 51.8 & 18 & 3 & 5 & $\mathrm{~S}$ \\
\hline $11: 45$ & 75.6 & 30 & 51.6 & 19 & 4 & 6 & ENE \\
\hline $11: 40$ & 74.6 & 30.1 & 51.3 & 19 & 3 & 5 & SSW \\
\hline $11: 35$ & 74.7 & 30.1 & 51.3 & 19 & 2 & 3 & SW \\
\hline $11: 30$ & 73.9 & 29.9 & 51 & 20 & 2 & 4 & ESE \\
\hline $11: 25$ & 73.9 & 30.3 & 51.1 & 20 & 3 & 6 & ENE \\
\hline $11: 20$ & 73.1 & 30.3 & 50.7 & 21 & 3 & 6 & WSW \\
\hline $11: 15$ & 73.1 & 30.3 & 50.7 & 21 & 3 & 6 & $\mathrm{~S}$ \\
\hline $11: 10$ & 73 & 30.3 & 50.7 & 21 & 5 & 7 & SE \\
\hline $11: 05$ & 72.7 & 30.8 & 50.7 & 21 & 5 & 7 & $\mathrm{E}$ \\
\hline 11:00 & 72.2 & 31.1 & 50.6 & 22 & 4 & 7 & $\mathrm{NE}$ \\
\hline
\end{tabular}

\subsection{Schmidt Hammer Test}

\subsubsection{Description of the Schmidt Hammer Test}

The Schmidt hammer test is an in-place method used for determining the strength of hardened concrete as specified by the American Society of Testing and Materials (ASTM) C805. The compressive strength ( $\mathrm{fc}^{\prime}$ ) is established by measuring the hardness (rebound value) of the concrete surface and comparing this to a conversion curve. It can also be used to measure the relative quality of concrete by identifying variations over a region. Variation testing over a region can lead to the location of weak spots and flaws, but the results are relative. Ideally, the concrete should have a relatively smooth, flat surface, and results should be compared to compression and flexural tests from the same concrete mass.

Calibration should best be done with cylinders of the same cement and aggregate as used on the structure being tested. This method is a quick way of obtaining an indication of strength, with accuracy of plus or minus 15 to $20 \%$ for specimens cast, cured, and tested under conditions for which calibration curves have been established. Results are only at the surface and are only a measure of compressive strength. Crack and flaw location and extent are not measurable except when present as gross surface characteristics. Nothing at depth is determined. The results are affected by factors such as smoothness of surface, size and shape of specimen, moisture condition of the concrete, type of cement and aggregate, and extent of surface carbonation or deterioration. 


\subsubsection{VSC-17 Hammer Test}

The INL project team performed hammer testing of the VSC-17 on October 5 and 10, 2005, following removal of paint from selected radial and vertical locations. Figure 15 shows testing being performed at the 270-degree position. What may appear to be residual paint in the work areas is actually exposed aggregate. The 90 and 270-radial locations have flat areas that were ground off to provide space for nameplate installation. Grinding the $1-\mathrm{ft}(30-\mathrm{cm})$-wide $\times 3-\mathrm{ft}(90-\mathrm{cm})$-high flats exposed the larger gravel aggregate.

Schmidt rebound hammer testing was performed at 70 locations on the concrete exterior surface of the VSC-17 VCC. The test locations were spaced at 45 degrees radially and at $2-\mathrm{ft}(60-\mathrm{cm})$ vertical intervals. At 45 and 90 degrees, tests were performed in 4-in. (100-mm) areas at 4-in. vertical intervals for 10 positions below the 45 -degree vent. Twenty hammer impacts were performed at each location (twice the minimum required by the ASTM C805-02 method); see Figure 16 . Of the 70 test areas, $28 \%$ had no data that departed from the mean by greater than six units, meaning that the high and low values were not removed from the average. The overall standard deviation among the 1400 data points was 3.37. This uniformity of rebound value was maintained even at the 45-degree location immediately below the upper vent, which was expected to have the greatest porosity based on radiation levels. Appendix E contains the entire data table for this test.

There were some small surface defects (approximately $0.1 \mathrm{in.} \mathrm{diameter} \mathrm{and} \mathrm{depth)} \mathrm{discovered} \mathrm{when}$ the paint was removed for impact testing. The degree of pitting seen here was not typical of other areas tested. Avoiding these as directed by the ASTM method, the relative compressive strength of concrete at this location was consistent with the remainder of the test areas. Figure 17 shows the surface of the cask concrete $4 \mathrm{in}$. below the upper vent following paint removal.

To gauge the readings received by hammer testing, a standard concrete test specimen was rebound tested and then broken at the INL Materials Testing Laboratory. The adjusted average rebound value for the first specimen was 37.1, while the second was 35.3. These specimens broke at 4,895 and 4,570 psi respectively; see Table 5. When extrapolated, the average value indicated for compressive strength of the VSC-17 shield concrete is approximately 6,600 psi. In typical circumstances, concrete gains compressive strength as it ages, but the expected increase is typically about $20 \%$. For the concrete used to construct the VSC-17 shield, that value should be on the order of 5,400 to 5,500 psi. In moist cured concrete, the value may increase by as much as $40 \%$, which would project the 28 -day average values from the cask fabrication pour from 4,509 psi to 6,312 psi at 5 years (Figure 18).

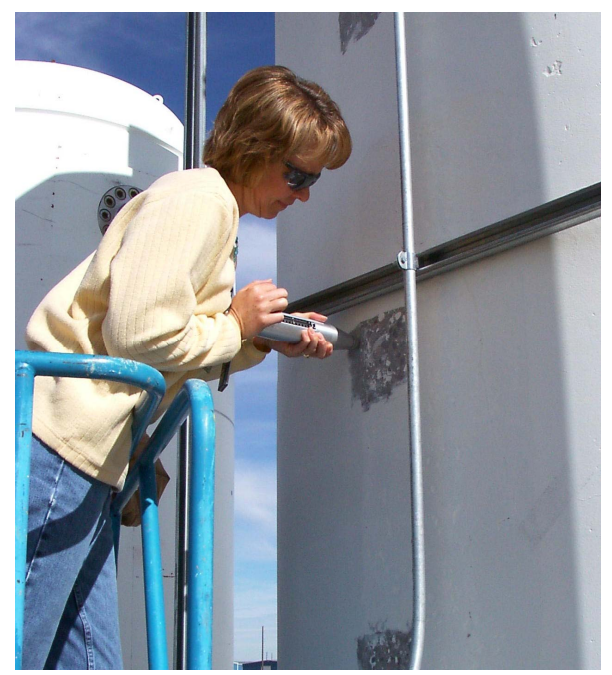

Figure 15. Schmidt rebound hammer testing on the VSC-17 cask. 


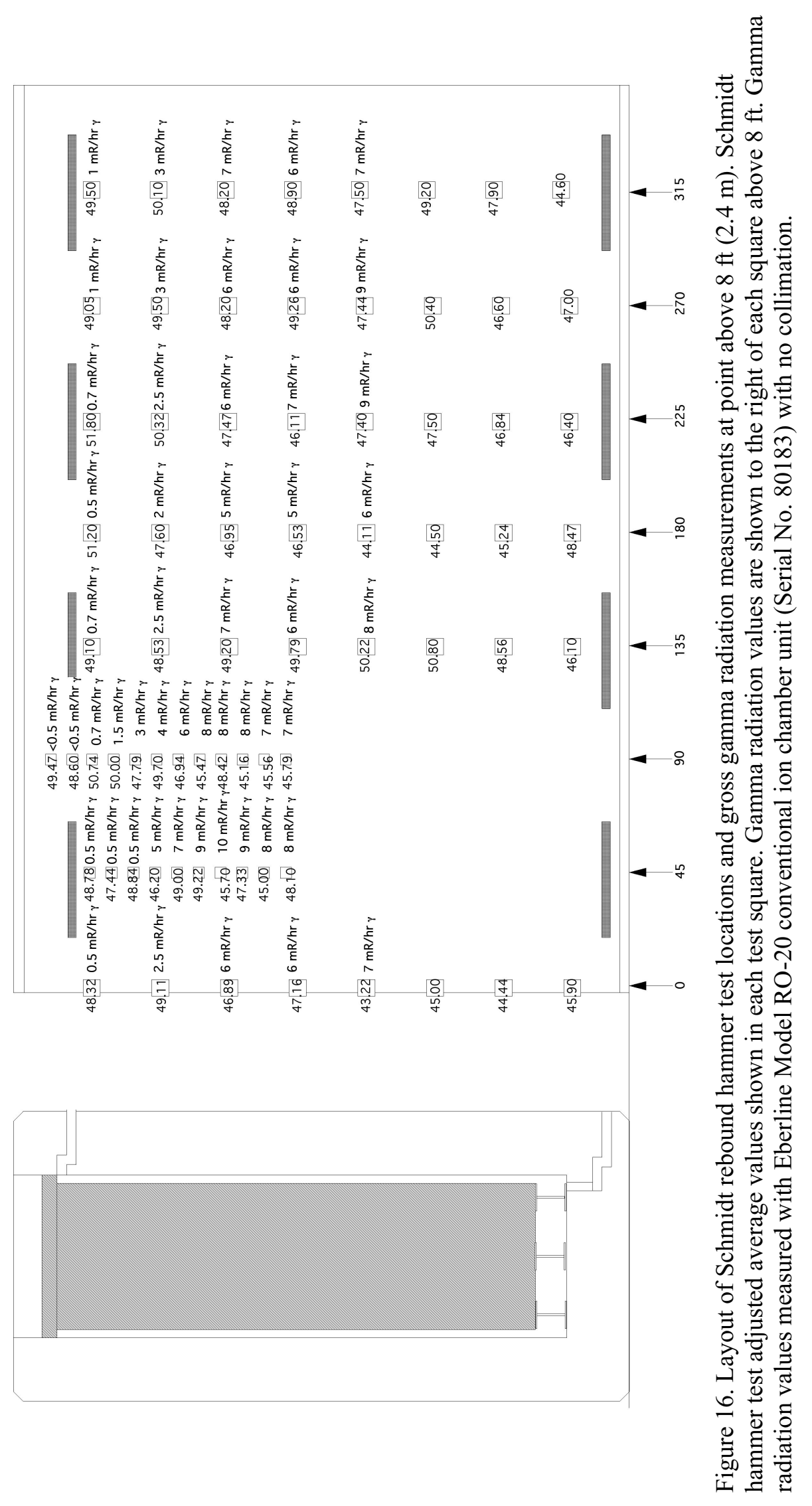




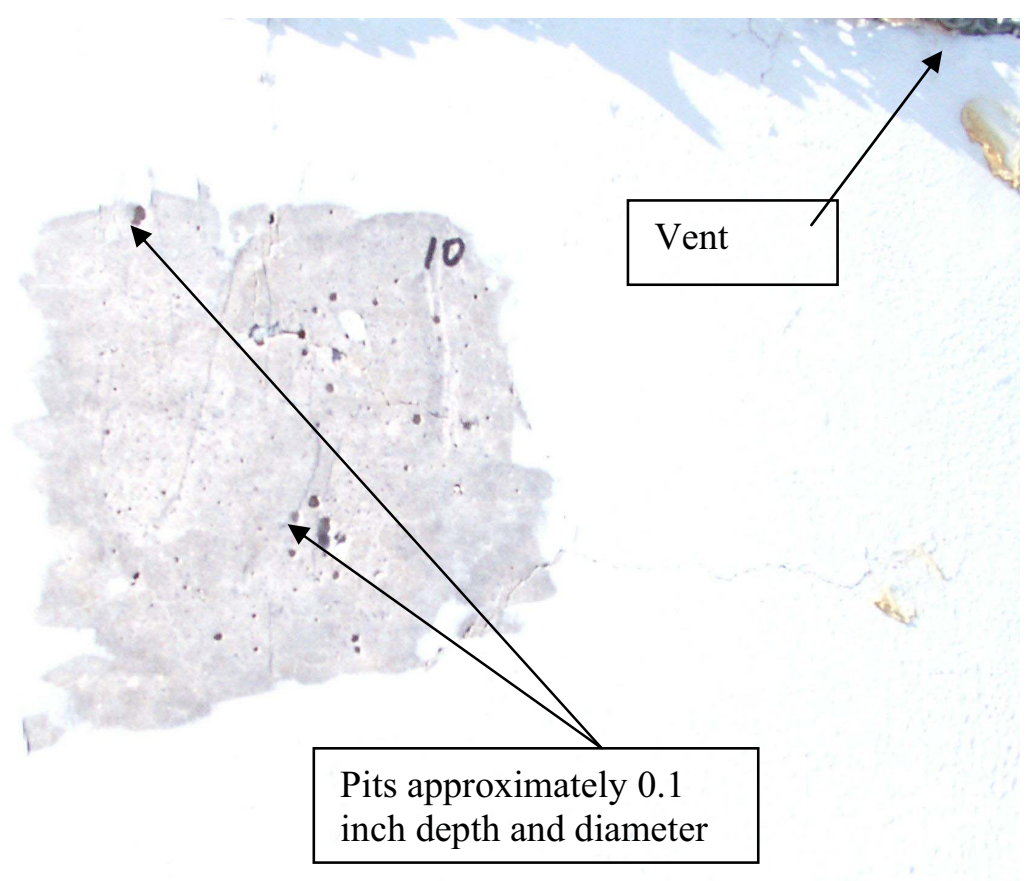

Figure 17. Pits at position 10, below the 45-degree vent.

Table 5. Test cylinder rebound hammer data.

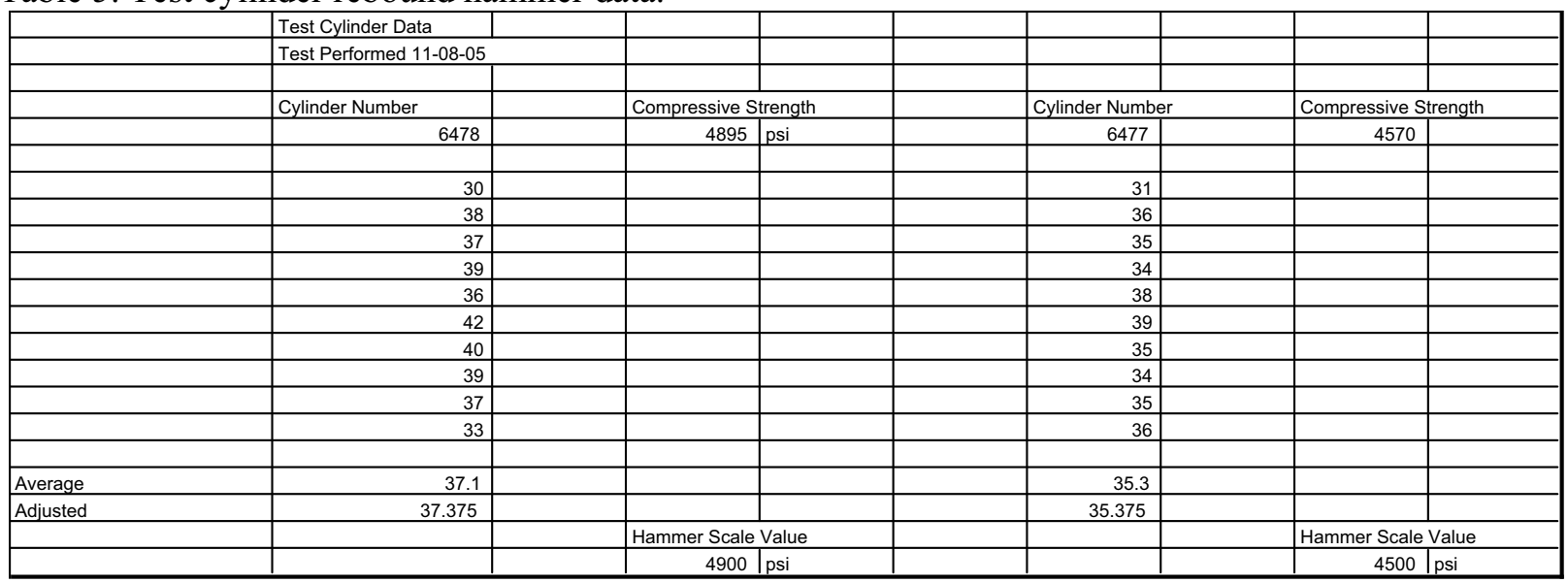

\subsection{Gamma Radiation Measurements}

Because of a need to reconcile the 2004 data with the 2003 measurements, collimated and uncollimated gamma ray measurements were made at the 52-degree position for vertical positions from 3 to $18 \mathrm{ft}$. The measurements made in 2005 suggest that the progressive increase of dose rate above $4 \mathrm{~m}$ is anomalous, the result of either incorrect recording or incorrect positioning of the detector during the 2003 measurements. Inconsistent values are believed to have been recorded due to problems getting all the equipment mounted on the lift platform to function simultaneously. The 2003 values from the 61-degree position appear to be consistent with the 2005 data. (The comparisons are shown in Figure 19.) Data are provided in tabular form as Table 6. 


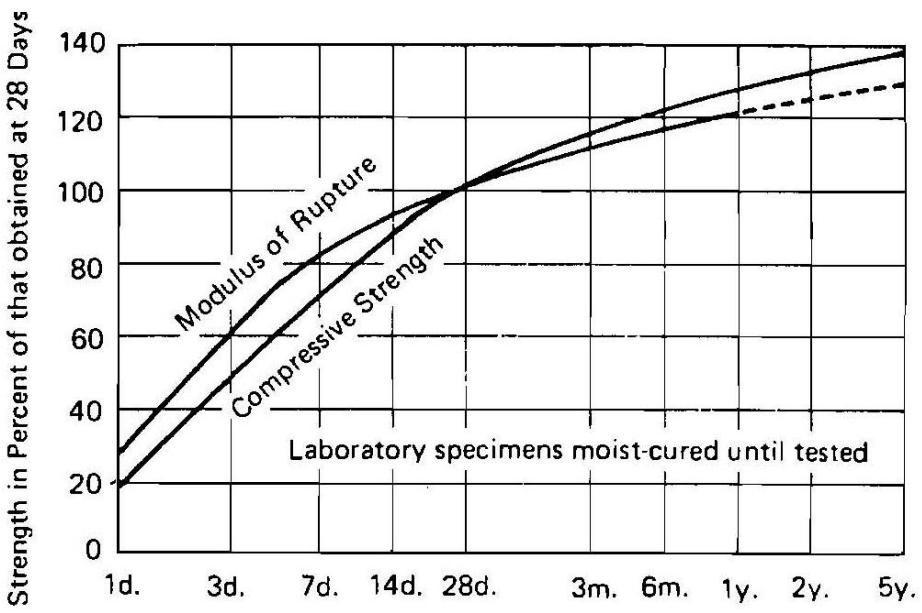

Age of Concrete (log scale)

Figure 18. Age-strength relationships for moist-cured concrete. ${ }^{3}$

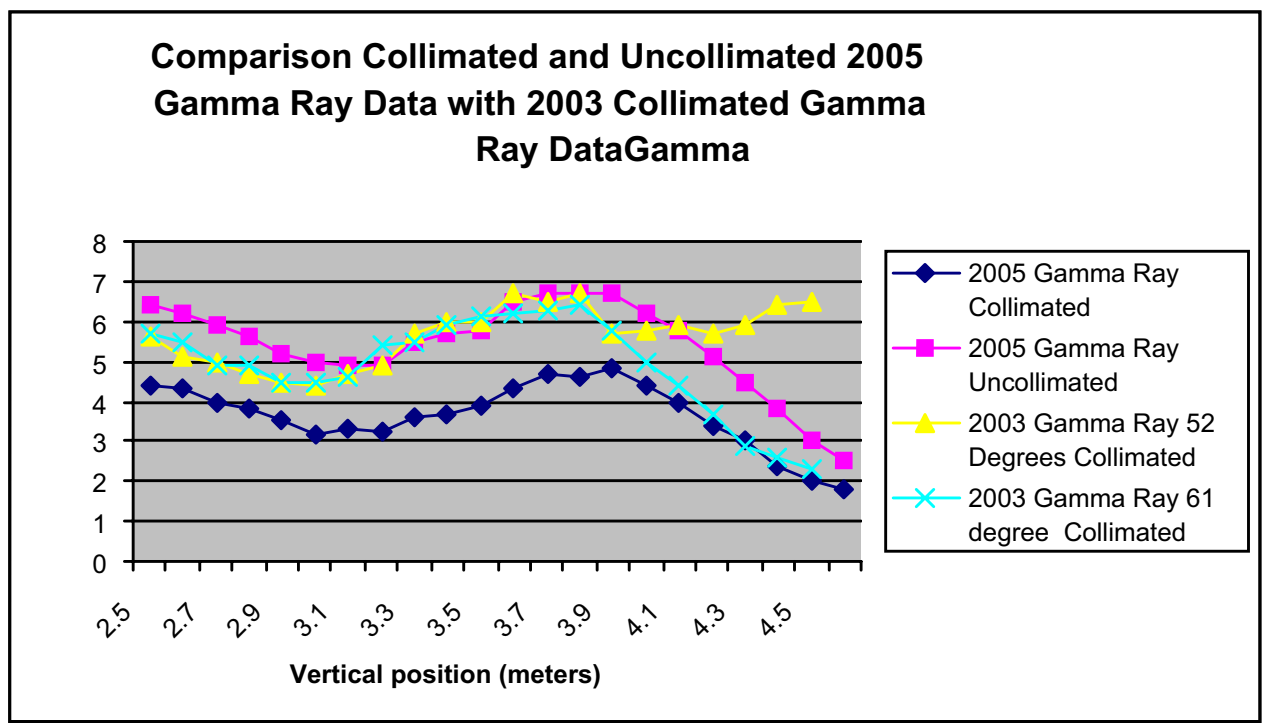

Figure 19. Comparison of 2003 and 2005 collimated measurements.

Review of the $2003 \log$ book for data acquisition indicates that inconsistent positioning of the detector with the value recorded resulted in the apparent increase in values above the 4-m position. On a less readily explained note, it appears that the 2005 measurements do not show the same step change at 2.4-m vertical position as seen in all 41 measurements in 2003.

\subsubsection{Measurements (with Clarifications for 2004 Report)}

The data shown graphically on page 12 of the 2004 report (Reference 2) have been combined with the 2003 and 2005 data to provide a comparison. The background values for radiation at the TAN-791 boundary rope (approximately $10 \mathrm{ft}[300 \mathrm{~cm}]$ from the cask) were $0.6 \mathrm{mR} / \mathrm{hr}$ in 2003 and $2 \mathrm{mR} / \mathrm{hr}$ in 2004. This difference was due to excavation and removal of tanks containing radioactive waste in an area adjacent to the cask pad. All sets of measurements were taken at the sixth 8 -in. interval (48 in.), corresponding to the 52-degree position. The increased background appears to be the biggest single 
Table 6. Comparison of gamma radiation readings for the 52-degree radial position. Data for comparison are visually shown in Figures 19 and 20.

\begin{tabular}{|c|c|c|c|c|c|c|c|c|c|}
\hline & & 2005 & 2005 & 2004 & 2004 & 2004 & 2003 & 2003 & 2003 \\
\hline & & 48 in (52 degrees) & & & & & 48 in (52 degrees) & 40 in (43 degrees) & 56 in (61 degrees) \\
\hline & & Collimated & Uncollimated & Collimated & Uncollimated & Uncollimated & Collimated & Collimated & Collimated \\
\hline & & Gamma & Gamma & Gamma & Gamma & Gamma & Gamma & Gamma & Gamma \\
\hline Height & Height & & & & TBM-232 & R0-20 & & & \\
\hline$(\mathrm{m})$ & (in) & $(\mathrm{mR} / \mathrm{h})$ & $(\mathrm{mR} / \mathrm{h})$ & $(\mathrm{mR} / \mathrm{h})$ & $(\mathrm{mR} / \mathrm{h})$ & $(\mathrm{mR} / \mathrm{h})$ & $\mathrm{mR} / \mathrm{hr}$ & $\mathrm{mR} / \mathrm{hr}$ & \\
\hline & 36 & & & 2.1 & & & 0.9 & 1 & 0.8 \\
\hline 1.0 & 40 & 0.5 & 0.9 & 1.9 & 2.9 & 3.7 & 0.8 & 0.9 & 0.8 \\
\hline 1.1 & 44 & 0.8 & 1.4 & 1.9 & & & 0.9 & 0.9 & 0.8 \\
\hline 1.2 & 48 & 1.2 & 2.1 & 2 & 4.1 & 4.8 & 0.8 & 0.9 & 0.8 \\
\hline 1.3 & 52 & 1.4 & 2.3 & 1.9 & & & 0.7 & 0.9 & 0.8 \\
\hline 1.4 & 56 & 1.7 & 2.6 & 2 & 5.2 & 6.6 & 0.8 & 0.9 & 0.9 \\
\hline 1.5 & 60 & 2.1 & 2.9 & 2.1 & & & 0.8 & 1.1 & 0.9 \\
\hline 1.6 & 64 & 2.1 & 3.4 & 2.1 & 6.4 & 8.5 & 0.8 & 1 & 0.8 \\
\hline 1.7 & 68 & 2.4 & 3.8 & 2 & & & 0.8 & 0.9 & 0.8 \\
\hline 1.8 & 72 & 2.8 & 4.2 & 2 & 8.1 & 10 & 0.9 & 1 & 0.8 \\
\hline 1.9 & 76 & 3.5 & 4.7 & 2 & & & 0.9 & 0.9 & 1 \\
\hline 2.0 & 80 & 4 & 5.4 & 1.9 & 8.7 & 11 & 0.9 & 0.9 & 1 \\
\hline 2.1 & 84 & 4.2 & 6 & 2 & & & 0.9 & 0.9 & 0.9 \\
\hline 2.2 & 88 & 4.4 & 6.2 & 1.9 & 9.1 & 11 & 0.8 & 0.9 & 0.8 \\
\hline 2.3 & 92 & 4.5 & 6.6 & 1.9 & & & 0.9 & 0.9 & 0.7 \\
\hline 2.4 & 96 & 4.6 & 6.7 & 2 & 8.3 & 10 & 0.9 & 1 & 0.8 \\
\hline 2.5 & 100 & 4.4 & 6.4 & 5 & & & 5.6 & 5.9 & 5.7 \\
\hline 2.6 & 104 & 4.3 & 6.2 & 4.6 & 7.5 & 9 & 5.1 & 5.5 & 5.5 \\
\hline 2.7 & 108 & 4 & 5.9 & 5 & & & 5 & 5.7 & 4.9 \\
\hline 2.8 & 112 & 3.8 & 5.6 & 5.1 & 7.2 & 9 & 4.7 & 4.8 & 4.9 \\
\hline 2.9 & 116 & 3.5 & 5.2 & 5.8 & & & 4.5 & 4.4 & 4.5 \\
\hline 3.0 & 120 & 3.2 & 5 & 6.1 & 7.8 & 9 & 4.4 & 4.6 & 4.5 \\
\hline 3.1 & 124 & 3.3 & 4.9 & 6.6 & & & 4.7 & 4.8 & 4.6 \\
\hline 3.2 & 128 & 3.21 & 4.9 & 6.8 & 8.4 & 10 & 4.9 & 5.2 & 5.4 \\
\hline 3.3 & 132 & 3.6 & 5.5 & 6.9 & & & 5.7 & 5.7 & 5.5 \\
\hline 3.4 & 136 & 3.7 & 5.7 & 6.9 & 8.9 & 12 & 6 & 5.8 & 5.9 \\
\hline 3.5 & 140 & 3.9 & 5.8 & $\mathrm{DL}$ & & & 6 & 6.3 & 6.1 \\
\hline 3.6 & 144 & 4.3 & 6.5 & $\mathrm{DL}$ & & 12 & 6.7 & 6.8 & 6.2 \\
\hline 3.7 & 148 & 4.7 & 6.7 & DL & & & 6.5 & 6.8 & 6.3 \\
\hline 3.8 & 152 & 4.6 & 6.7 & $\mathrm{DL}$ & 7.9 & 8 & 6.7 & 6.8 & 6.4 \\
\hline 3.9 & 156 & 4.8 & 6.7 & $\mathrm{DL}$ & & & 5.7 & 6 & 5.8 \\
\hline 4.0 & 160 & 4.4 & 6.2 & $\mathrm{DL}$ & 5.5 & 8 & 5.8 & 5.2 & 5 \\
\hline 4.1 & 164 & 4 & 5.8 & $\mathrm{DL}$ & & & 5.9 & 4.9 & 4.4 \\
\hline 4.2 & 168 & 3.4 & 5.1 & $\mathrm{DL}$ & INACC & INACC & 5.7 & 4.1 & 3.7 \\
\hline 4.3 & 172 & 3 & 4.5 & $\mathrm{DL}$ & & & 5.9 & 3.4 & 2.9 \\
\hline 4.4 & 176 & 2.4 & 3.8 & $\mathrm{DL}$ & INACC & 3.8 & 6.4 & 2.9 & 2.6 \\
\hline 4.5 & 180 & 2 & 3 & $\mathrm{DL}$ & & & 6.5 & 2.5 & 2.3 \\
\hline 4.6 & 184 & 1.8 & 2.5 & & INACC & 2.8 & & & \\
\hline 4.7 & 188 & 1.4 & 2.2 & & & & & & \\
\hline 4.9 & 192 & 1.2 & 1.9 & & 2.4 & 2.7 & & & \\
\hline
\end{tabular}

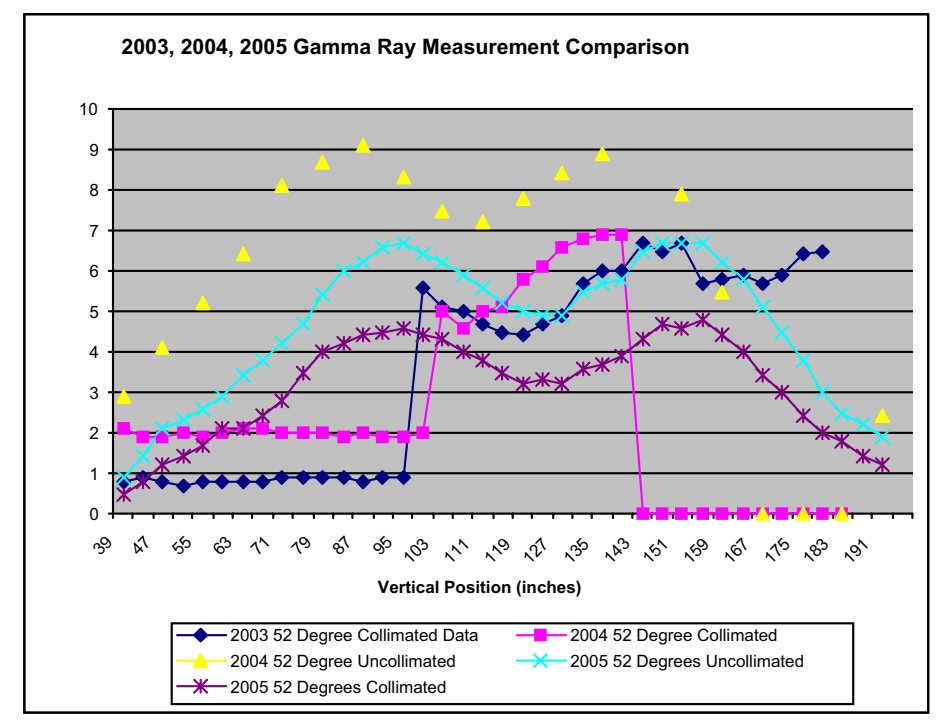

Figure 20. Comparison of 2003 and 2005 gamma radiation data. 
contributor to the difference in both the collimated and uncollimated 2004 data. However, it is not immediately apparent why the uncollimated response varies in a manner consistent with the rise in activity seen in both collimated and uncollimated 2005 data. The high activity at the bottom of the cask appears to be due entirely to background, because it was identified with both the TBM-232 and the Eberline RO-20 ion chambers.

The background at the radiation rope at the CPP-2707 pad at INTEC in 2005 was $<0.5 \mathrm{mR} / \mathrm{hr}$, which is consistent with the $0.5 \mathrm{mR} / \mathrm{hr}$ readings seen at the lower positions on the cask.

A possible justification for the radiation profile, and especially the trough at approximately $120 \mathrm{in}$. seen in the 1989, 2004, and 2005 measurements, is the presence in the MSB Storage Sleeve Assembly of a 1.75-in.-thick $\times 3.5$-in.-wide $\times 28$-in.-long piece of steel at that location (Item 4, Drawing M17-004). Although this is present in the 180-degree position of the basket, it is not present in the 225-degree position.

\subsection{Ultrasonic Testing Process}

In August 2005, CRIEPI and their subcontract team from LAZOC Sensing Technology joined the INL project team to perform ultrasonic testing on the VSC-17. Figure 21 shows the CRIEPI team applying sensors to the VSC-17 and gathering data. A second revision of this report will be published to provide details of this testing and its conclusion.

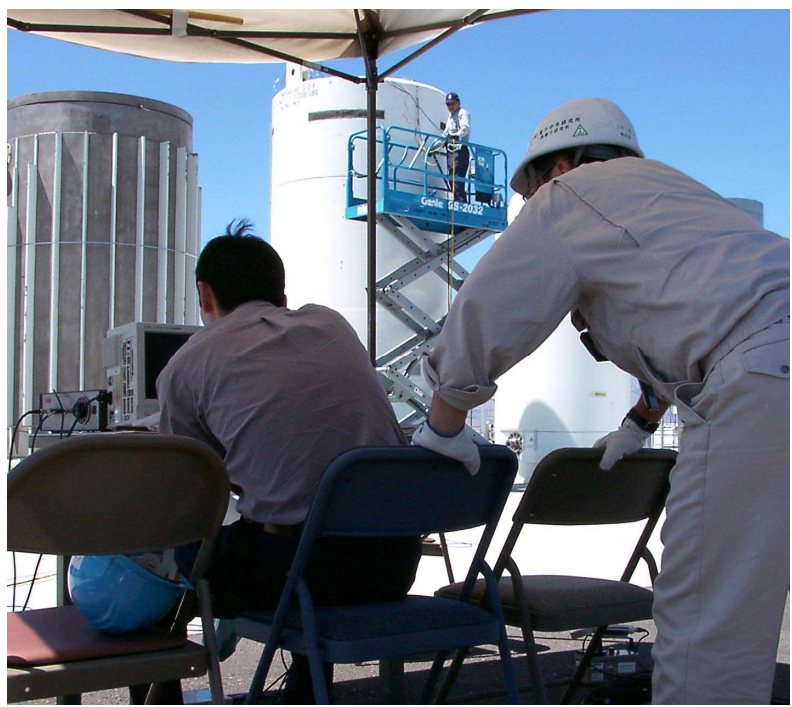

Figure 21. CRIEPI and LAZOC Inc. representatives performed ultrasonic testing in August 2005. 


\section{SUMMARY}

The temperature data from 2005 indicate that there is limited variation of temperature throughout the cask. This suggests that heat transfer is relatively uniform, and high temperatures occur at the vents as a result of hot airflow. There is no indication of temperature discontinuity that results from shield component material variability.

The Schmidt rebound hammer data show minimal variability among the data points on the cask. Substantial departures from the mean value occurred only where pits were approximately the diameter of the hammer impact point and in areas where the aggregate is exposed.

Variations in the radiation field between the lower and upper sections do not conclusively result from the construction of the cask. There is no indication that the lower material is denser or stronger based on ultrasonic and hammer testing. There is a substantial indication that the radiation hot spot identified under the 45 to 52 degree upper vent is a construction artifact. This is possibly a void underneath the metal vent shielding offset that was not completely filled in with concrete. 


\section{REFERENCES}

1. Krishna Vinjamuri, E. M. Feldman, C. K. Mullen, B. L. Griebenow, A. E. Arave, and R. C. Hill, Dry Rod Consolidation Technology Project at the Idaho National Engineering Laboratory, EGG-WM-8059, April 1988.

2. D. A. Carlson, C. R. Hoffman, S. L. Morton, A. M. Neilson, C. P. Oertel, J. M. Rivera, P. L. Winston, and L. A. VanAusdeln; Radiation, Thermal and Visual Examination of the VSC-17 Cask Annulus, INEEL/EXT-04-02329, September 2004.

3. Mark Fintel, editor, Handbook of Concrete Engineering, Van Nostrand Reinhold, New York, 1974. 